\title{
Late Palaeozoic palynomorph assemblages from the Karoo Supergroup and their potential for biostratigraphic correlation, Kalahari Karoo Basin, Botswana
}

\author{
BENSON N. MODIE \& ALAIN LE HÉRISSÉ
}

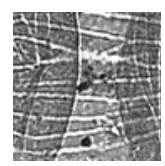

\begin{abstract}
Late Carbonifeous to Permian core samples from two borehole sections, STRAT 1 and CKP 6, that penetrate the glacial to postglacial and coal-bearing Lower Karoo sequence, Kalahari Karoo Basin, Botswana, contain well preserved pollen and spore palynomorphs. The palynomorph assemblages comprise 165 species of spores and pollen, and few acritarchs and chlorophycean algae. This paper presents a local biozonation of three succeeding assemblage zones, recognisable in each borehole section. The assemblage zones are named: the Hamiapollenites bullaeformis Biozone, the Cyclogranisporites gondwanensis Biozone and the Platysaccus papilionis-Striatopodocarpites fusus Biozone, in ascending order of stratigraphy. Assemblages are compared and correlated with assemblages described from other Gondwana areas of Africa, Australia, Arabia, South America and Antarctica. A general analysis of taxa from the Kalahari Karoo Basin indicates a distinct similarity with assemblages from the Paraná Basin of South America. The Hamiapollenites bullaeformis Biozone is comparable with the Vittatina costabilis Interval Zone of the Paraná Basin. Assemblages from the Cyclogranisporites gondwanensis and the Platysaccus papilionis-Striatopodocarpites fusus zones are comparable with the Lueckisporites virkkiae Interval Zone. Age determination for the assemblages in the Kalahari Karoo Basin is inferred from comparison with similar assemblages from previous Gondwana studies, and ranges from the Late Carboniferous (Kasimovian-Gzhelian) to latest Early or possibly earliest Middle Permian (Late Cisularian to Early Guadalupian). • Key words: Kalahari Karoo Basin, Late Carboniferous-Permian, pollen, spores, assemblage zones.
\end{abstract}

Modie, B.N. \& LE HÉRISSÉ, A. 2009. Late Palaeozoic palynomorph assemblages from the Karoo Supergroup and their potential for biostratigraphic correlation, Kalahari Karoo Basin, Botswana. Bulletin of Geosciences 84(2), 337-358 (11 figures). Czech Geological Survey, Prague. ISSN 1214-1119. Manuscript received January 16, 2009; accepted in revised form May 30, 2009; published online June 19, 2009; issued June 30, 2009.

Benson N. Modie (corresponding author), The Centre for Knowledge, P.O. Box 1382, Lobatse, Botswana; tesbnm@gmail.com • Alain Le Hérissé, Université de Brest, CNRS, UMR 6538 Domaines Océaniques, Institut Européen de la Mer, CS 93837, 6 Avenue V. Le Gorgeu, 29238 Brest Cedex 3, France

\begin{abstract}
Although the coal-bearing Karoo Supergroup sequence of the Kalahari Karoo Basin (Fig. 1) is known to be extensive in Botswana (e.g. Smith 1984), geological insight into stratigraphic correlation remains minimal. This is greatly compounded by the lack of surface exposure for outcrop analysis and correlation due to extensive cover by a thin veneer of Cainozoic superficial deposits of the Kalahari Desert environment (Thomas \& Shaw 1991, Carney et al. 1994). The heavy reliance on the traditional method of stratigraphic subdivision, based only on lithological similarities, to correlate widely spaced borehole sections in the Kalahari Karoo Basin is not unequivocal. For example, studies of sedimentary environments and facies distributions have shown that similar units can be deposited at different times, in different areas and with no
\end{abstract}

physical connection to each other (Reading 1986, Mial 1990). The lack of extensive surface exposure in the Kalahari Karoo Basin and few macrofossils, leaves palyno$\log y$ as the most effective method of dating and correlating the subsurface sequences. Evidence from previous palynological studies (e.g., MacRae 1978, Dolby 1990, ECL 1990, Cadman 1995, Key et al. 1995, Stephenson \& McClean 1999) indicates that the Lower Karoo sequence contains pollen and spore microfossils suitable for stratigraphic applications. The results of a recent study (i.e. Modie 2007), on which this paper is largely based, have also revealed an overwhelming presence of pollen and spore palynomorph assemblages suitable for biostratigraphic analysis. The purpose of this paper, therefore, is to give an account of the nature of palynomorph assem- 


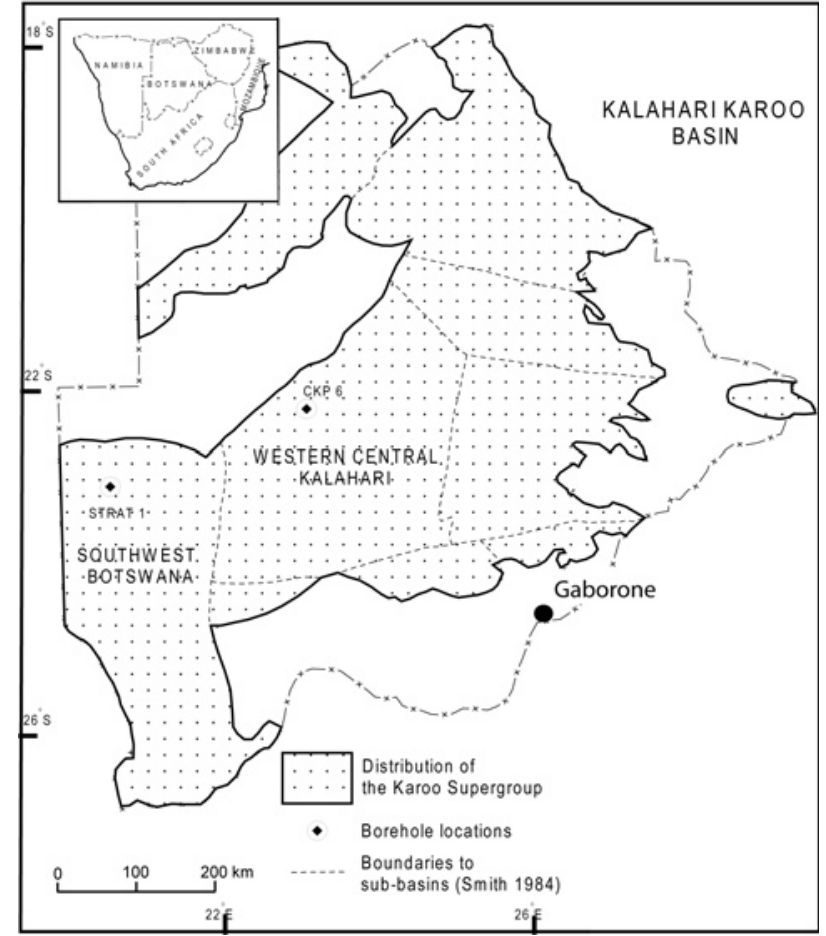

Figure 1. Locality map indicating the position of study boreholes: inset shows the location of Botswana in the region.

blages obtained from the Lower Karoo sequence as well as discuss and highlight their significance to stratigraphic zonation.

\section{Geological setting}

The Kalahari Karoo Basin of Botswana is one among several contemporaneous Karoo basins (Smith et al. 1993, Johnson et al. 1996, ECL 1998) of southwestern Gondwana (e.g., Fig. 2) that became active in the Permo-Carboniferous times, with the earliest deposits laid down during the Late Palaeozoic glacial event. The exact geodynamic setting for the Kalahari Karoo Basin, as well as for the other related Karoo basins, remains little understood. However, several previous workers, amongst them Daly et al. (1991), Cox (1992), ECL (1998) and Turner (1999), consider the origin of these basins to be linked to collision induced extensional tectonics related to the Late Palaeozoic to Early Mesozoic Gondwanide Cape orogeny (e.g., Thomas et al. 1992). The latter resulted from the subduction of a palaeo-Pacific plate under southern Gondwana, which subsequently led to the development of a retro-arc foreland basin, represented by the Main Karoo Basin in South Africa. The Kalahari Karoo Basin and other subsidiary basins in the north, developed as intracratonic rift basins, in response to the orogenic push from the south (e.g., Daly et al. 1991, ECL 1998).

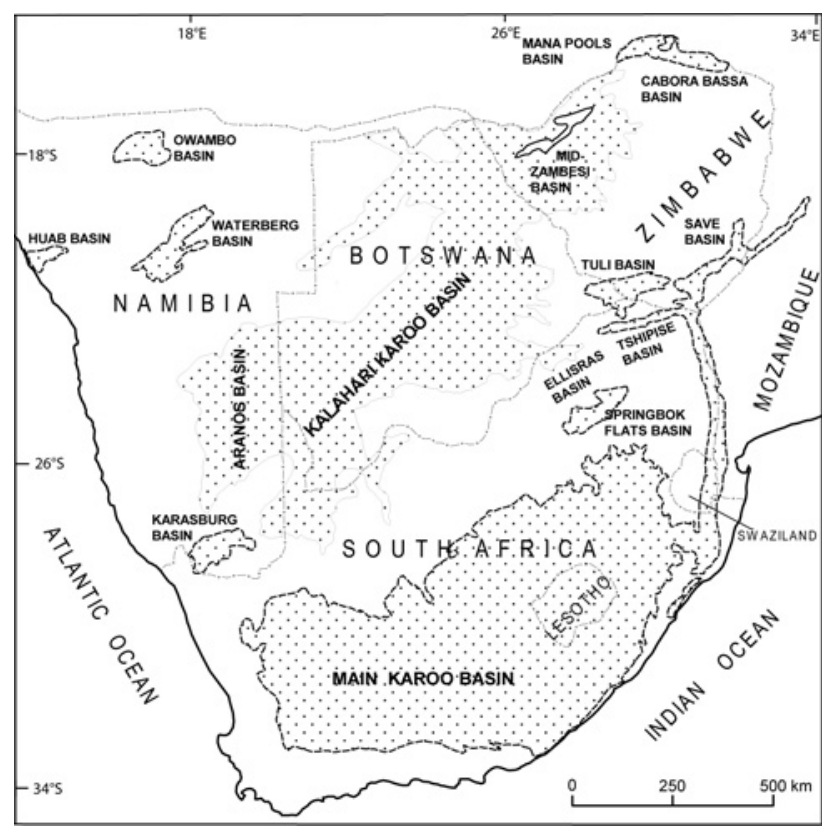

Figure 2. The regional location of the Karoo basins of southern Africa (after Johnson et al. 1996).

The sub-surface structural framework of the Kalahari Karoo Basin is little understood due to widespread cover by sediments of the Kalahari Desert environment. Consequently, much of the covered centrally located Kalahari Karoo Basin has hitherto been considered to represent an intracratonic sag basin. Only along the eastern fringe of the basin, where there is limited exposure and near-surface bedrock, has it been possible to demonstrate the occurrence of fault-bounded graben structures (Green et al. 1980). In recent times though, the use of geophysical data (e.g., seismic, aeromagnetics etc.) to delineate major structural elements, such as faults and lineaments, indicates a rift basin setting for parts of the covered interior of the Kalahari Karoo Basin (Davison \& Steenkamp 1995). Generally, both pre- and syn-Karoo fault systems are considered to have had a local influence on the distribution and thickness of the Karoo sequence (ECL 1998).

Stratigraphic sub-division (Fig. 3) of the sequence in the Kalahari Karoo Basin is largely based on lithological comparisons. On a regional scale, the lithostratigraphy is sub-divided into lower and upper sequences based on the location of a major regional mid-Karoo unconformity (ECL 1998). Sequences that belong to the lower Karoo include the Dwyka, Ecca and Beaufort groups, whilst those that belong to the upper Karoo include the Lebung and Stormberg Lava groups. Overall, the entire sequence in the Kalahari Karoo Basin, as in most other Karoo basins in the region, records a transition from a glacial period through fluvio-deltaic and swampy settings and ultimately turning arid before sedimentation came to a halt due to the extrusion of continental flood basalts (Smith 1984, Smith et al. 
1993, Johnson et al. 1996). The Karoo basaltic volcanism, considered to have been initiated by extensional tectonics that marked the beginning of the Gondwana break-up, represents a major regional magmatic event in Karoo geology that occurred between 185-177 Ma ago (Jourdan et al. 2005).

\section{Materials and methods}

This paper is based on samples sourced from drill-cores provided by the Botswana Department of Geological Survey, as part of a broader project to investigate Karoo basin stratigraphy (Modie 2007). Two well-sampled cored-boreholes, STRAT 1 and CKP 6, provided 120 and 95 samples, respectively, for palynological investigations. STRAT 1 and CKP 6 boreholes are located in separate sub-basins of the Kalahari Karoo Basin i.e. Southwest Botswana and Western Central Kalahari sub-basins, respectively (Fig. 1). The stratigraphic range of sampling from STRAT 1 borehole covered the Dwyka and Ecca groups. Sampling from CKP 6 borehole covered the entire Karoo Supergroup clastic sequence i.e. from the Dwyka Group to the Lebung Group. All samples were prepared at the Laboratoire de Palaeontologie, Université de Brest, France, where all sample residues, as well as all specimens illustrated in this paper, are presently kept. Samples were processed using standard palynological methods (e.g. Wood et al. 1996). Palynological slides prepared for each sample were examined using a transmitted-light microscope (i.e. Leica DIAPLAN) to perform routine slides analyses for the systematic descriptions of palynomorphs.

\section{Palynomorph content}

A total of one hundred and ninety-one productive samples, from both STRAT 1 and CKP 6 boreholes, yielded 165 spore and pollen taxa, and 19 acritarchs and chlorophycean algae, which are listed in Appendix 1. The range of the taxa and proposed biozonation are indicated in Figs 4 and 5. All productive samples are from the Lower Karoo sequence i.e. Dwyka, Ecca and Beaufort groups, with the latter, however, only yielding very poorly preserved palynomorphs in the basal sections. Samples from the upper Karoo sequence i.e. Lebung Group, which is largely dominated by red beds, are barren. The palynomorphs recovered from the lower Karoo are dominated by pollen and spores (e.g., Figs 4, 5), however a few samples also indicate the rare occurrences of microphytoplanktons (acritarchs and prasniphycean phycomata). There is a visible disparity in the preservation status of palynomorphs from STRAT 1 and CKP 6 , which perhaps reflects the palaeo-depositional settings of separate sub-basins where the two boreholes are located.

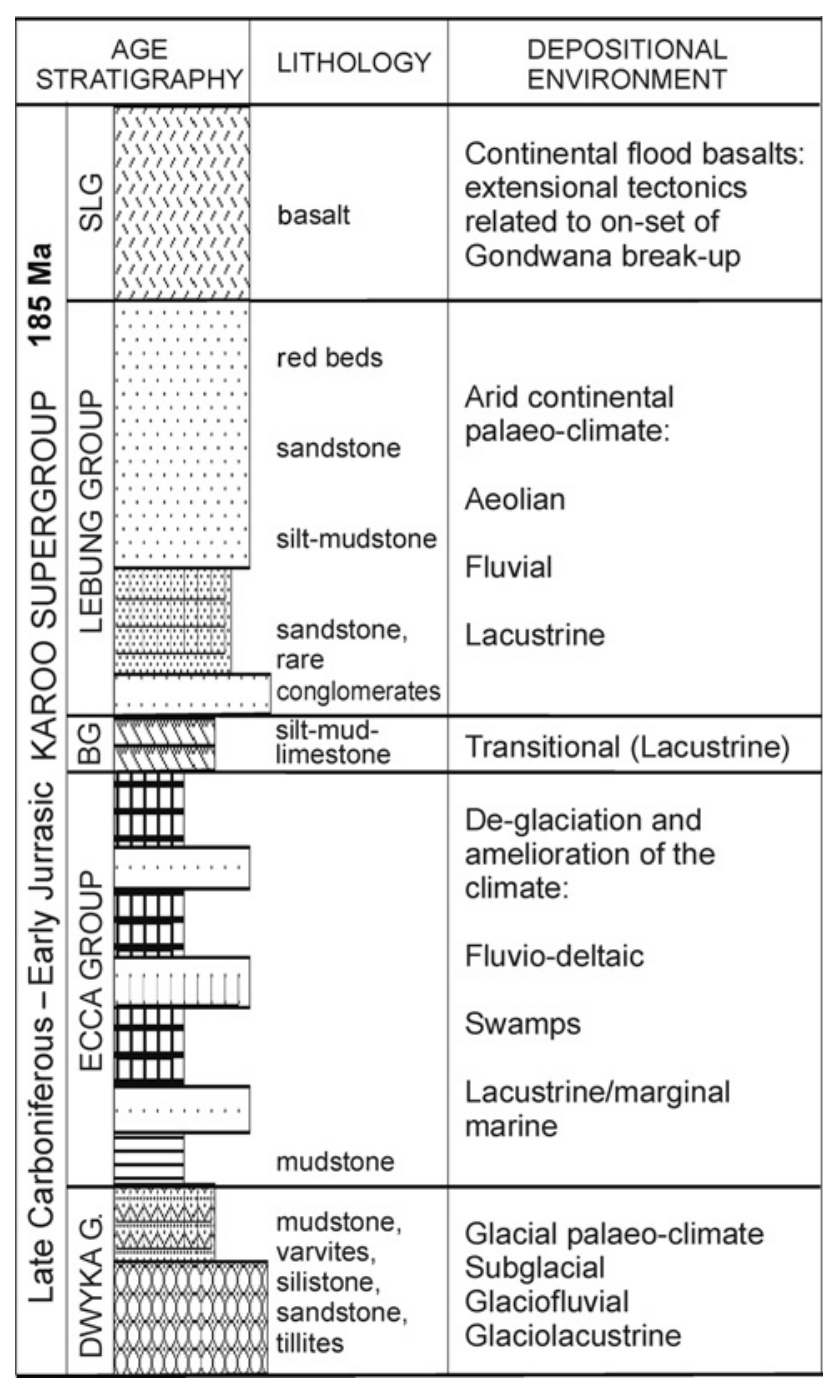

Figure 3. Karoo Supergroup lithostratigraphic subdivision and palaeoenvironments.

The palynomorph content indicates a strong lithofacies influence, with the sandstone facies producing the poorest yields in comparison with the siltstone and mudstone facies. This observation is considered to reflect preferential sorting with respect to grain-size.

\section{Biozonation}

A detailed assessment of the palynomorph content i.e. qualitative analysis, revealed the occurrence of taxa suitable for subdividing the Lower Karoo sequence into biostratigraphic units or biozones. Although the range charts could not produce a perfect correlation between STRAT 1 and CKP 6, consideration of the common taxa in terms of the assemblage zones, allowed the strata in both sections to be subdivided into three biozones which are assemblage zones (Figs 4, 5). 
Comparison of the data between STRAT 1 and CKP 6 indicates that the base of the sections is characterised by a few common taxa of typically long range nature. There is some disparity in occurrence data between the two sections, which makes the level of comparison in the basal sections rather poorly constrained. The most significant taxon that reflects some degree of correlation between the basal sections is the rare and relatively short to medium range Punctatisporites ubischii species. A perhaps significant point to consider with regard to the basal sections is the fact that these marks the junction between older taxa of pre-Karoo strata and those originating in early Karoo times. However, in the case of this study, the youngest pre-Karoo sequence consists of barren earliest Cambrian red beds, which unfortunately are not useful for a stratigraphic review of taxa ranges.

\section{The Hamiapollenites bullaeformis Assemblage Zone (Biozone KK 1)}

The lower limit of the zone is placed at the lowermost occurrences of taxa Apiculatisporis parmatus and Potonieisporites brasiliensis. The upper limit of the zone is placed at the last occurrences of taxa Punctatisporites gracilis, Densosporites rotundus, and Cristatisporites microvacuolatus. The zone has been named after the species Hamiapollenites bullaeformis, which forms one of the diagnostic taxa, and is restricted to the zone in both STRAT 1 and CKP 6, and occurs in other regionally associated areas.

The diagnostic taxa characteristic of this zone are represented by spores, with the most common being: Converrucosisporites, Cristatisporites, Horriditriletes and Punctatisporites spp. The most significant taxa are: Apiculatisporis unicus, Cirrabaculisporites spp., Converrucosisporites pseudoreticulatus, Converrucosisporites irregularis, Cristatisporites inconstans, Cristatisporites menendezii, Divaricrassus minor, Horriditriletes curvibaculosus, Lophotriletes rarus, Lundbladispora gracila, Punctatisporites gretensis, Punctatisporites parvus, Raistrickia crenata and Retusotriletes diversiformis. The Vittatina Bisaccate Group appears in this biozone. It also contains important pollen taxa such as Caheniasaccites flavatus, Cycadopites cymbatus, Pakhapites fusus, Protohaploxypinus rugatus, Potonieisporites congoensis, Weylandites lucifer. The most notable similarity between STRAT 1 and CKP 6, in terms of species range, is a major decrease in diversity indicated by the Cristatisporites spp. at the top of the zone. Coincidently, the top of the zone in both sections also mark a major lithofacies change from a predominantly argillaceous facies, and hence reflecting the possibility of facies-control of the Cristatisporites spp. In general, the rest of the zone indicates a close affinity between the ranges of the taxa and the lithofacies distribution, an observation that may indicate the restriction of ranges due to ecological variations and the geographical isolation of taxa (Miall 1990). Nevertheless, some of the less common but significant and restricted species, such as Hamiapollenites bullaeformis and Raistrickia crenata appear to have their terminations not closely associated with the top boundary of the zone and hence are probably not related to changes contributing to litho-facies variations. Therefore, the ranges of Hamiapollenites bullaeformis and Raistrickia crenata are considered to broadely represent time-equivalent events occurring in STRAT 1 and CKP 6. However, in order to improve the confidence level in the reality of this zone, these events require to be verified from other sections as well as searching for other diagnostic taxa in future studies. It should be noted that Granulatisporites angularis, present in the biozone, with a long range in the two sections is considered here as a junior synonym of Granulatipsorites austroamericanus Archangelsky \& Gamerro, 1979. The latter is also considered a possible junior synonym of Microbaculispora tentula Tiwari, 1975, by Playford \& Dino (2002). Some specimens referred to in this study as Converrucosisporites irregularis (Anderson) comb. nov., are similar to some Pseudoreticulatispora pseudoreticulata of Backhouse (1991) which exibit a large morphological variation. We also put in synonymy with Converrucosisporites pseudoreticulatus (Balme \& Henelly) comb. nov., Converrucosisporites confluens (Archangelsky \& Gamerro) Playford \& Dino, 2002, which is well represented in the biozone. In terms of the lithostratigraphic divisions this zone corresponds to the lowermost Ecca Group (i.e. Bori/Kobe formations) and the Dwyka Group. However, the lower boundary of the zone indicates the possibility of diachronosity, with the upper Dwyka section in CKP 6 reflecting time equivalence with the lower Dwyka in STRAT 1.

\section{The Cyclogranisporites gondwanensis Assemblage Zone (Biozone KK 2)}

This is a rather poorly defined zone (Figs 4, 5), which is characterised largely on long-range and some mediumrange taxa. Compared to the Hamiapollenites bullaeformis Assemblage Zone, this zone has only a slight dominance of spores over pollen in its list of diagnostic taxa. The most striking characteristic of this zone in both STRAT 1 and CKP 6 is a drop in the consistency of frequency of occurrence of taxa, a feature related to the change in the lithofacies observed at the upper limit of the Hamiapollenites buellaeformis Assemblage Zone. As a result, there is a lack of common restricted species to form diagnostic taxa and provide time equivalent events for correlation. The lower limit of this zone is determined by the upper limit of the prece- 

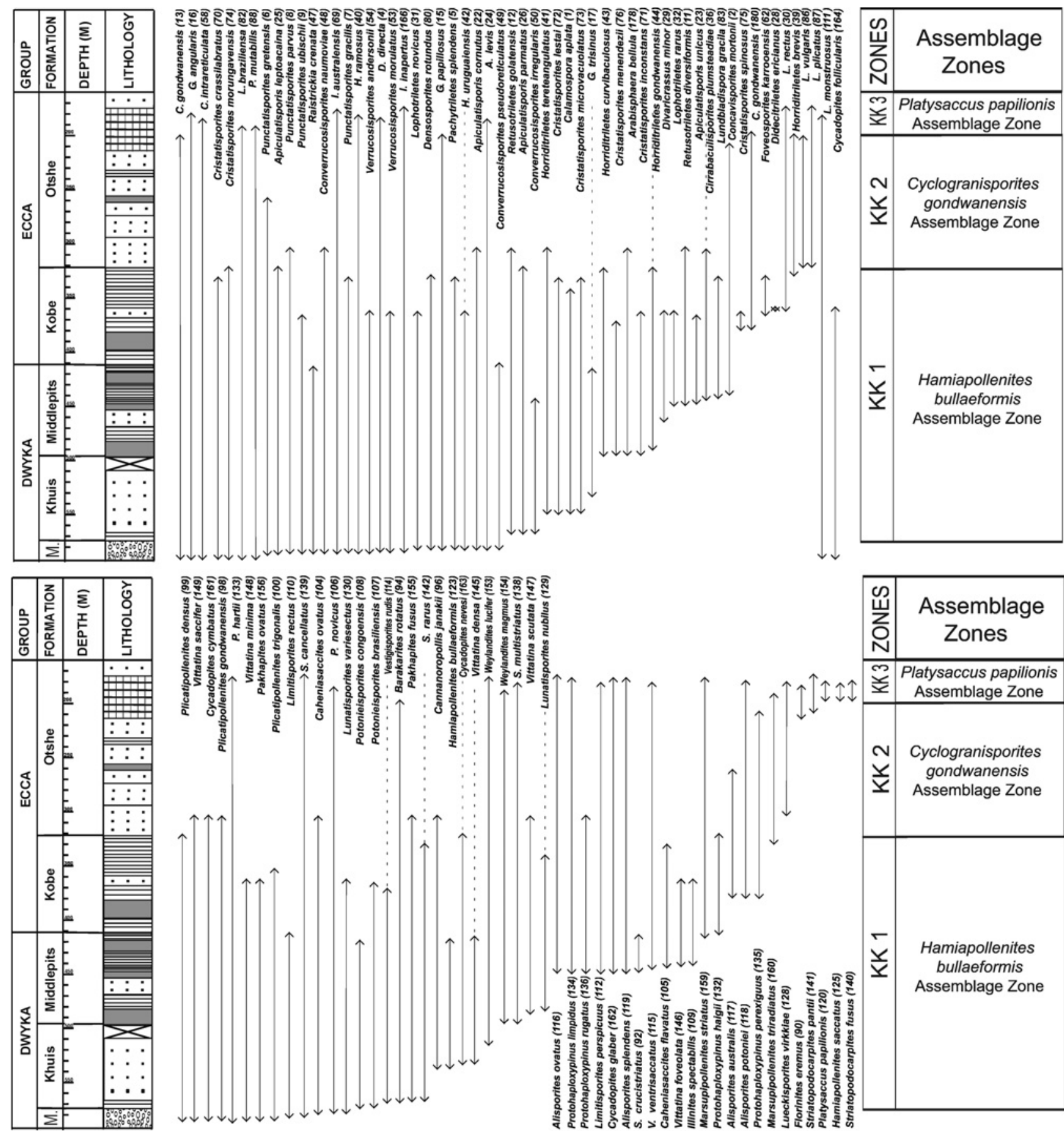

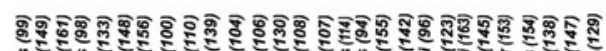
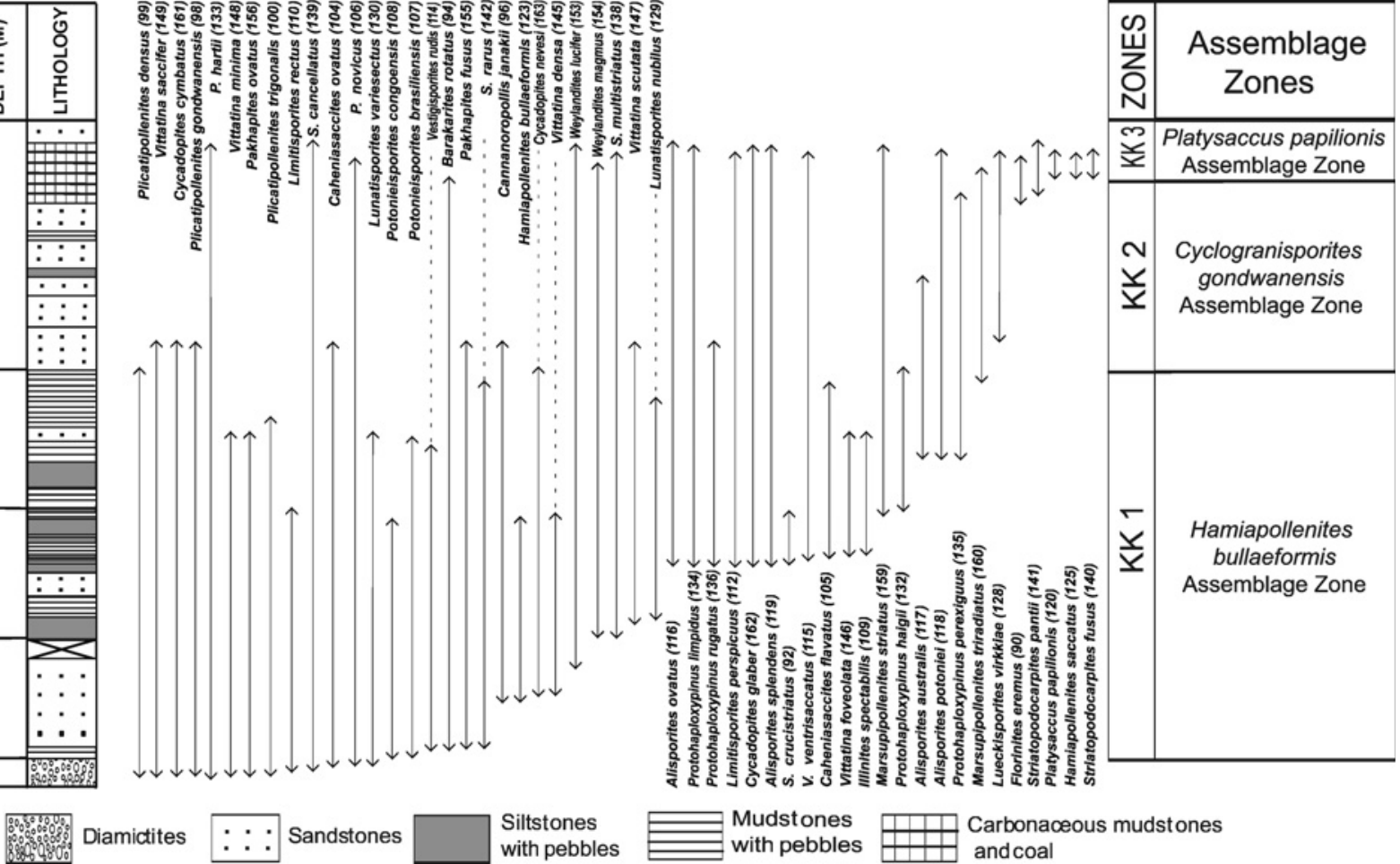

Mudstones
with pebbles

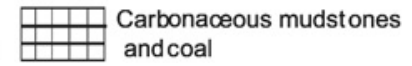

Figure 4. Lithology and range chart of spore and pollen species identified in core samples from STRAT 1 borehole, with inferred palynozonal attributions.

ding zone i.e. Hamiapollenites bullaeformis Assemblage Zone. The upper limit of the zone is placed at the last occurrence of the taxon Cyclogranisporites gondwanensis. The latter has provided a name for the zone because it is the only species that defines the upper limit in both STRAT 1 and CKP 6 borehole sections. The Biozone
KK 2 is also characterized by, amongst others: Alisporites australis, Alisporites ovatus, Alisporites potoniei, Concavisporites mortonii, Horriditriletes brevis, Laevigatisporites vulgaris, Lophotriletes rarus, Lueckisporites virkkiae, Protohaploxypinus perexiguus and Marsupipollenites triradiatus. 


\section{The Platysaccus papilionis-Striatopodocarpites fusus Assemblage Zone (Biozone KK 3)}

This zone (Figs 4, 5) represents a narrow uppermost productive section of the sampled strata, dominated by bisaccate pollen. The lower limit of the zone is placed at the first occurrence of the taxa Platysaccus papilionis and Striatopodocarpites fusus. The upper limit is not defined due to the non-availablity of core material for sampling beyond the topmost sampled level. Consequently, this zone possibly represents a lowermost subzone of a broader zone. The zone is named after these two species because they are the most significant taxa restricted within the zone, as noted in borehole STRAT 1 and CKP 6, as well as in equivalent zones from other previous local studies. The species Luekisporites virkkiae ranges into Biozone KK 3 in STRAT 1, and Laevigatisporites vulgaris on the other hand appears in the same range in CKP 6 whereas it disappears in STRAT 1. Other diagnostic short range taxa in the biozone are: Vestigisporites ventrisaccatus, common to the two cores and Florinites eremus, Hamiapollenites saccatus, Polypodiisporites mutabilis and Striatopodocarpites pantii.

\section{Correlation with previous local studies}

Most of the limited palynology studies undertaken from Botswana either present only palynostratigraphic interpretations in terms of biostratigraphic units and their ages or assemblage descriptions without occurrence data (e.g., Dolby 1990, Key et al. 1995). This approach presents problems for comparison and correlation due to the unavailability of ranges of taxa, and as a result, only broad comparisons can be considered. A few of the previous studies however (e.g., MacRae 1978, ECL 1990, Stephenson \& McClean 1999) do present results that give insight into the vertical characteristics of taxa, which allows for a limited but significant comparison and correlation (e.g., Fig. 6).

Correlation with the zonation scheme of MacRae (1978). Although displaying some considerable variations in taxonomic terminology, the unpublished work of MacRae (1978) presents the first complete preliminary palynozonation scheme available for correlation. The scheme comprises three concurrent range zones based on the distribution of sixty eight miospore taxa, namely zones I, II, and III, in ascending order of the stratigraphy, and recognised in borehole N1/3 situated in the northeast part of the basin. A broad comparison (Fig. 6) indicates that the section of STRAT 1 that corresponds to Biozone KK 1 can be correlated with MacRae's Biozone 1. Species most significant and common to both sections include: Vittatina minima, Caheniasaccites flavatus, Caheniasaccites ovatus, Plicatipollenites densus, Plicatipollenites gondwanensis, Punctatisporites gretensis and Calamospora aplata. The stratigraphic range of the common taxa indicates a correlation of the middle to upper Dwyka Group (e.g., Khuis and Middlepits formations) and lower Ecca Group (e.g., Kobe Formation) in STRAT 1 with a much condensed similar section of the Karoo Supergroup described in MacRae (1978). The upper section of STRAT 1, which includes biozones KK 2, KK 3, and the topmost section of Biozone KK 1 can be broadly correlated with the section covered by MacRae's concurrent range zones II and III in N1/3. Species common to both sections include: Alisporites splendens, Striatopodocarpites fusus, Protohaploxypinus limpidus, Alisporites ovatus and Laevigatosporites vulgaris. A comparison of the suprageneric quantitative trends reveals a rise in the relative abundance of bisaccate striate pollen in both sections. Overall, STRAT 1 allows for only a broad and general comparison. As a result there are no visible details that make it possible to comparatively analyse the lithofacies for important factors such as diachronous characteristics.

Correlation with the zonation scheme of ECL (1990). ECL (1990) erected a regional zonation scheme of five palynozones based on analysis of borehole and field samples from Namibia, Botswana, Zimbabwe, and Zambia. The palynozonation scheme of ECL (1990) is largely based on variations determined by the relative abundance of taxa, which makes it difficult to correlate with the present study in which the zonation is largely based on species' ranges. Nevertheless, few diagnostic taxa allow for a broad comparison and correlation (Fig. 6). The first half of Biozone KK 1 of STRAT 1 can be correlated with Zone I (MZ I) on the basis of common taxa that are dominated by monosaccates and consist of Plicatipollenites gondwanensis and relatively diverse Potoniesporites spp. Other species of note, albeit in different taxonomic terminology, include Vestigisporites rudis and Cristatisporites morungavensis. The second half of Biozone KK 1 is correlated with Zone MZ II and the base of Zone MZ III on the basis of the common occurrence of Cirrabaculisporites plumsteadi, an increase in non-striate pollen in the upper part of the zones and finally the upper limit of the regular monosaccates i.e. Plicatipollenites and Cannanoropollis species. The KK 2 Biozone is correlated with the upper part of Zone MZ III and Zone MZ IV, based on the occurrence of common significant taxa including Lueckisporites virkkiae, Marsupipollenites triradiatus and Laevigatosporites spp. Other characteristic taxa interesting in terms of correlation include Protohaploxypinus spp., Weylandites lucifer and Cycadopites cymbatus. The uppermost KK 3 Biozone is correlated with Zone MZ V based on a first appearance of Striatopodocarpites pantii as well as the following common taxa: Lueckisporites virkkiae, Weylandites lucifer, Polypodiisporites mutabilis and Laevigatosporites vulgaris. The base of the zone is generally reflected by a marked increase in the relative abundance of the striate bisaccates. 


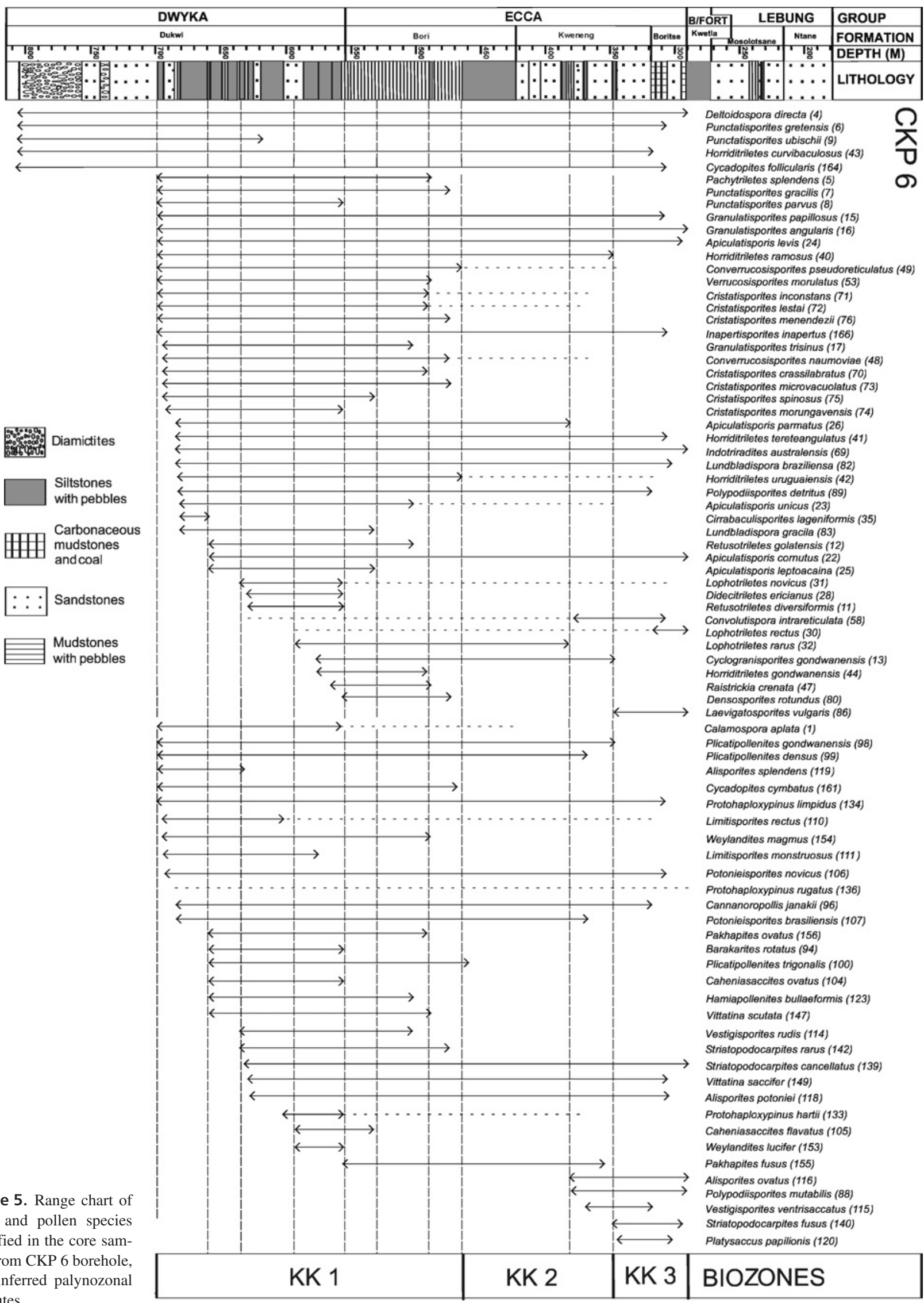




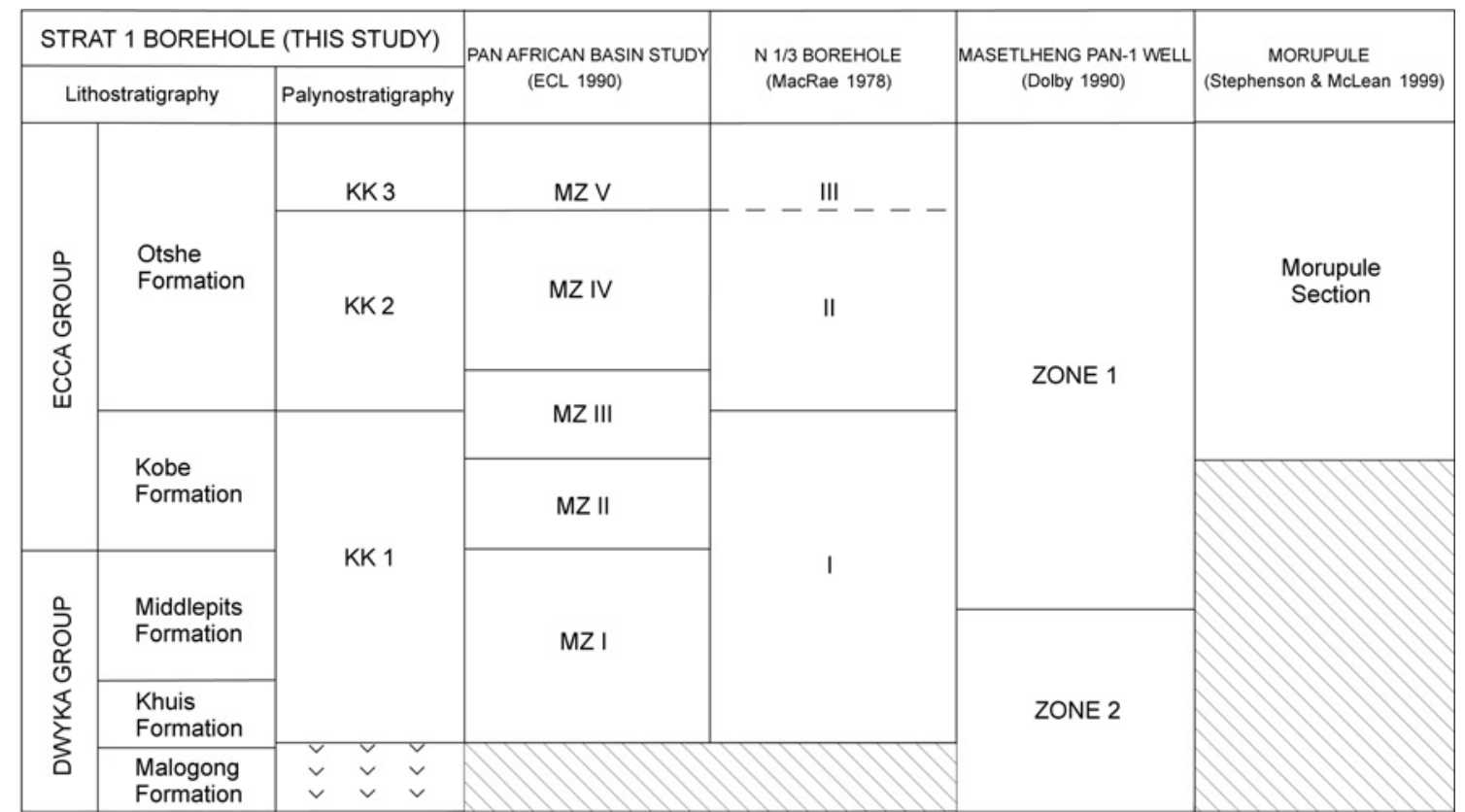

Figure 6. Correlation of the zonation scheme from STRAT 1 borehole (core section for reference) with zonation schemes from previous local studies.

Correlation with the work of Stephenson \& McLean (1999). - Stephenson \& McLean (1999) described an Early Permian palynological assemblage from a Lower Karoo sequence, represented by the Morupule Formation, in the eastern fringe of the Kalahari Karoo Basin. There is remarkable similarity between STRAT 1 and the Morupule section in terms of taxa content, albeit with some variations in taxonomic terminology. However, the majority of the common species depict a long range characteristic in the relatively extensively sampled STRAT 1 section. The Morupule Formation represents a narrow zone in terms of Karoo strata and less than $15 \mathrm{~m}$ was sampled by Stephenson \& McLean (1999). Consequently, the initiations and terminations of most taxa most likely fall outside the sampled section and hence species ranges remain poorly constrained. Nevertheless, comparison of the common taxa allows only for a broad and general tentative correlation (Fig. 6). The most comparatively significant taxa that correlate STRAT 1 to the Morupule section include Laevigatosporites vulgaris, Alisporites ovatus, Alisporites potoniei, Florinites eremus, Protohaploxypinus limpidus, Striatoabieites multistriatus and Platysaccus spp. The ranges of the significant taxa broadly correspond to biozones KK 2 and KK 3 of STRAT 1.

\section{Correlations with regional palynological studies}

Palynological studies pertinent to Karoo Supergroup stratigraphy have been undertaken by various workers in several of the contemporary Karoo basins of southwestern Gon- dwana (e.g. Manum \& Duc Tien 1973; Jardiné 1974; Falcon 1975-1978; Utting 1976, Anderson 1977; Wright \& Askin 1987; MacRae 1988; Hankel 1992-1993; Aitken 1994; d'Engelbronner 1996; Nyambe \& Utting 1997; Kalkreuth et al. 1999; Millsteed 1994-1999; Semkiwa et al. 2003 etc.). The results of such studies reveal some important common features that allow for a regional comparison and correlation of the Karoo sequence in the various basins. A selected number of the regional studies are discussed below and compared with the results from STRAT 1 section (e.g., Fig. 7).

\section{South Africa}

Correlation with the zonation scheme of MacRae (1988). MacRae (1988) described palynomorph assemblages from the northern Karoo basins of South Africa and subsequently erected six palynozones i.e. A-F, with which a broad correlation with STRAT 1 borehole is possible (Fig. 7). MacRae's (1988) Biozone A is tentatively correlated with the basal section of STRAT 1 where although no significant taxa exist for direct correlation, common taxa of rather long ranges occur. The top of Biozone B is equated with the upper part of Biozone KK 1 based on the terminations of Plicatipollenites trigonalis and Vestigisporites rudis, both of which occurs in the two zones. On the other hand, the base of Biozone B favourably equates with the base of Biozone KK 1 as defined on the basis of the initiation of the following species: Weylandites lucifer, Verrucosisporites pseudoreticulatus, Horriditriletes tereteangulatus and 
Striatoabieites multistriatus. Biozone C (MacRae 1988), described as the least palynologically productive, favourably equates with the top of Biozone KK 1, characterised by a remarkable decrease in the frequency of occurrence as well as the termination of most species, and the base of Biozone KK 2 of STRAT 1. The top boundary of Biozone KK 2 equates with the top boundary of Biozone D on the basis of the range termination of Laevigatosporites vulgaris in STRAT 1, even though the species is known higher up in CKP 6. Biozone KK 3 is correlated with Biozone E, albeit with difficulty, due to the lack of any common significant trends for direct correlation. A perhaps more significant observation is the occurrence of Platysaccus papilionis and Striatopodocarpites fusus, both of which are restricted to this zone in STRAT 1. The assemblage of common taxa among these zones includes: Deltoidospora directa, Striatoabieites multistriatus, Weylandites lucifer, Alisporites potoniei, Indotriradites australensis, Apiculatisporis levis, Protohaploxypinus limpidus, Protohaploxypinus hartii and Striatopodocarpites cancellatus.

Lithologicallly, the overall trend deduced from comparative analysis of the palynological assemblages reflects a diachronous Karoo sequence between the north Karoo basins of South Africa (e.g., borehole ET 61 in MacRae 1988) and the sequence at STRAT 1 borehole, especially with regard to the basal successions. MacRae's (1988) biozones A and B which largely fall within the lower Ecca Group succession (i.e. Wellington Formation) but also include a much condensed section of the Dwyka Group, correlate to a large extent with the Dwyka Group (i.e. Malogong, Khuis, and Middlepits formations), as well as a basal section of the Ecca Group (i.e. Kobe Formation) in STRAT 1 borehole. Similarly, Biozone C (MacRae 1988), which represent the lower parts of the middle Ecca succession (i.e. Enkelbult Formation), correlates with the uppermost part of the lower Ecca (i.e. Kobe Formation), but also encroaches into the basal section of the middle Ecca, in STRAT 1 borehole. The uppermost successions, although relatively poorly constrained due to low palynomorph yields, indicate a much closer lithological correlation between the respective successions. The latter reflects the possibility of a shift from a diachronous setting to a near time equivalent deposition during the middle to upper Ecca.

\section{Zimbabwe}

Correlation with the scheme of Falcon (1975). - Palynostratigraphic studies from the Mid-Zambezi Karoo Basin in Zimbabwe by Falcon (1975) allow for a broad but limited correlation (Fig. 7), based on rare similarities reflected by qualitative and quantitative analyses. Falcon (1975) erected a zonation scheme that subdivided the Lower Karoo sequence in the Mid-Zambezi Basin into four major assemblage zones, including eight sub-zones. Biozone KK 1 in STRAT 1 borehole can be equated with Falcon's (1975) Assemblage I. One notable and comparable characteristic are the ranges of Converrucosisporites pseudoreticulatus and Cycadopites cymbatus species, both considered significant for Assemblage I. However, only Converrucosisporites pseudoreticulatus form a significant taxon in the basal section of Biozone KK 1 of STRAT 1. The quantitative analyses also indicate some rare but significant similarities, which include a relatively marked upward increase in the zonolaminatitriletes, as well as an increase in the bisaccates pollen defining the top boundary. A rare direct comparison is reflected by the initiations of Retusotriletes diversiformis and Alisporites ovatus which both correlate the base of Falcon's (1975) Assemblage Sub-Zone B with the middle part of Biozone KK 1 of STRAT 1. The biozones KK 2 and KK 3 can be equated with Falcon's (1975) Assemblage II, albeit with difficulties. The lower boundary for the correlated zones is placed at the level where there is a marked upward increase in the relative abundances of bisaccates pollen. Taxa of notable and comparable ranges include Marsupipollenites spp., Striatoabieites spp., Striatopodocarpites spp., Laevigatosporites spp., Alisporites splendens and Alisporites potoniei. The introduction of Laevigatosporites spp. appears to be the most significant in defining the lower boundary for correlation.

\section{Zambia}

Correlation with the zonation scheme of Utting (1976). Two palynological assemblages described by Utting (1976) from the Lower Karoo Luwumbu Coal Formation of the Luangwa Valley in Zambia broadly compare (Fig. 7) with the assemblages identified in STRAT 1. Based on comparison of limited taxon ranges, the section of borehole STRAT 1 corresponding to Biozone KK 1 can be equated with the older assemblages obtained from the Mukumba Siltstone Member. The few comparable and characteristic taxa, occasionally with variable taxonomic nomenclature, include Plicatipollenites densus, Plicatipollenites trigonalis, Converrucosisporites pseudoreticulatus and Cristatisporites lestai. The latter assemblage broadly correlates the Dwyka Group and the Kobe Formation (i.e. lower Ecca Group) of the Kalahari Karoo Basin with the Mukumba Siltstone Member of the Luwumbu Coal Formation in Zambia. The upper section of STRAT 1 corresponding to biozones KK 2 and KK 3, compares favourably with the younger assemblage determined from the Mpwashi Carbonaceous Member. The most significant taxa in terms of comparative analysis of the ranges include Laevigatosporites spp., Alisporites potoniei, Protohaploxypinus perexiguus, Marsupipollenites striatus, Weylandites lucifer and Striatoabieites spp. This assemblage allows for a broad correlation of a section of the Otshe 


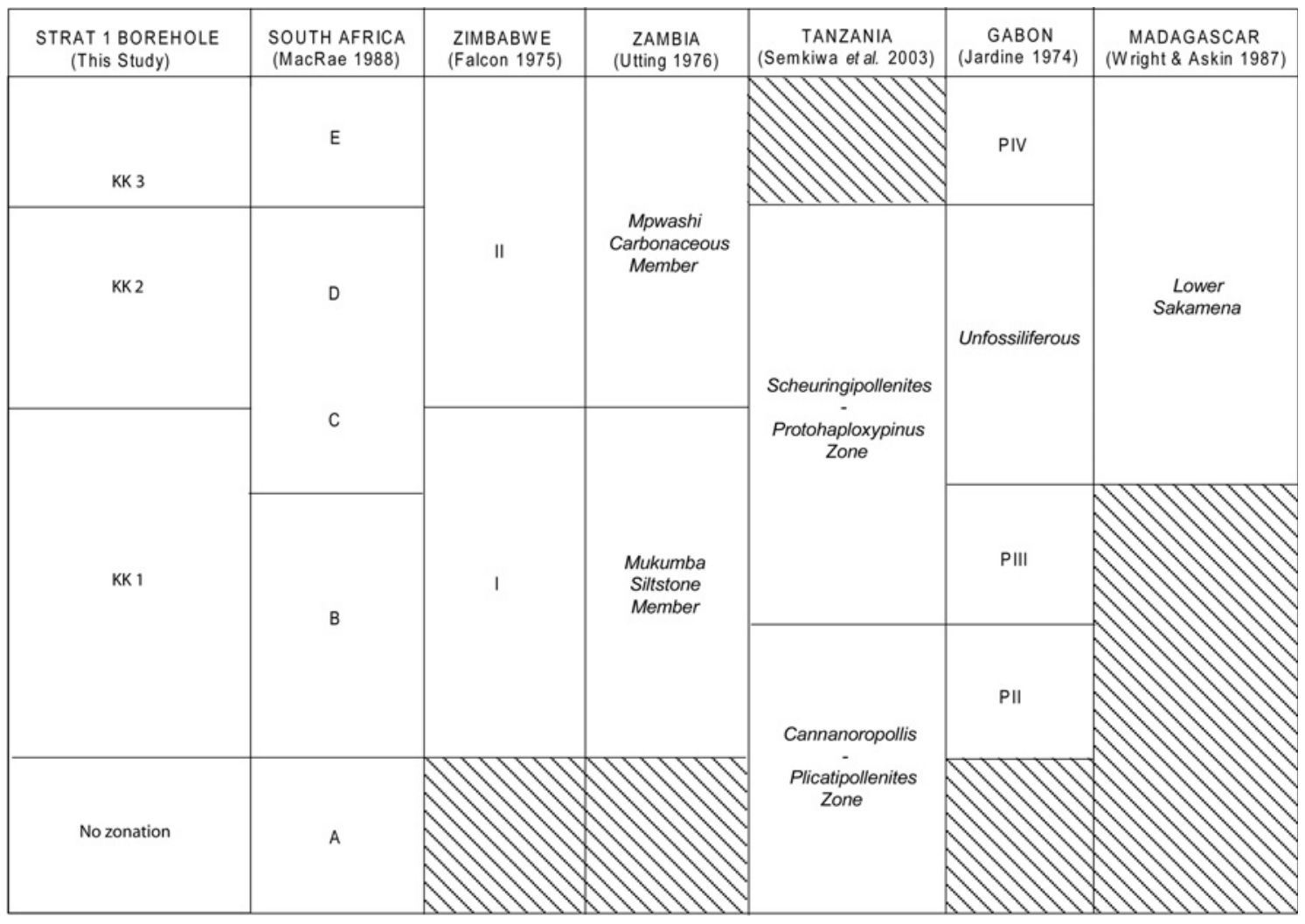

Figure 7. Correlation of STRAT 1 zonation scheme with a select few zonation schemes from previous regional studies.

Formation which corresponds to the middle Ecca, with the Mpwashi Carbonaceous Member of the Luwumbu Coal Formation in Zambia.

\section{Tanzania}

Correlation with the zonation scheme of Semkiwa et al. (2003). - Semkiwa et al. (2003) gave a brief account of palynological analysis from the Lower Karoo sequence of the Songwe-Kiwira Coalfield in Tanzania. A comparison of common taxa reflects the possibility of a broad correlation between STRAT 1 section and the sequence at Songwe-Kiwira Coalfield (Fig. 7). The basal section of Biozone KK 1 can be equated with the CannanoropollisPlicatipollenties Zone on the basis of the common occurrence of monosaccates, dominated by Cannanoropollis spp. and Plicatipollenites spp. There is also a notable similarity with regard to the common occurrence of Cristatisporites spp. This comparison generally correlates the Dwyka Group with the Idusi Formation at the Kiwira Coal Mine. The upper sections of STRAT 1 reveal a much more evident similarity as reflected by the occurrence of several species of comparable ranges. The most significant taxa include Alisporites ovatus, Alisporites potoniei, Laevigatosporites spp., Marsupipollenites striatus, Protohaploxypi- nus limpidus, Protohaploxypinus rugatus, Vittatina scutata and Weylandites lucifer. This assemblage allows for a correlation of the section corresponding to the upper half of Biozone KK 1 and Biozone KK 2 with the Scheuringipollenites-Protohaploxypinus Zone (e.g., Semkiwa et al. 2003). This consequently equates a section of the uppermost Dwyka, as well as the Kobe Formation and much of the Otshe Formation with the Mchuchuma Formation of the Songwe-Kiwira Coalfield in Tanzania.

\section{Kenya}

Correlation with the zonation scheme of Henkel (1992). Henkel (1992) documented Late Permian to Early Triassic assemblages from the Karoo Sequence of the Mombasa Basin in Kenya. Sampling for this work covered a very narrow section of the Maji ya Chumvi Formation, which makes correlation very poor and largely inconclusive. Of the two assemblages described, only the older assemblage, which unfortunately is limited to one sampling level, can be loosely equated with biozones KK 2 and KK 3. Taxa considered for comparative analysis include: Lueckisporites virkkiae, Weylandites spp., Plicatipollenites spp., Platysaccus spp., Striatopodocarpites spp. and Protohaploxpinus spp. 


\section{Gabon}

Correlation with the scheme of Jardiné (1974). - Palynological studies by Jardiné (1974) on Karoo equivalent sequences revealed three palynological assemblages from the "Série de l'Agoula", which overlies glacial deposits. The lowermost assemblage P II can be equated (e.g., Fig. 7) with lower part of Biozone KK 1 in STRAT 1 on the basis of common characteristic taxa such as Pakhapites fusus, Pakhapites ovatus, Caheniasaccites ovatus and Striomonosaccites spp. The succeeding assemblage P III is loosely correlated with upper part of Biozone KK 1 based on the significant common occurrence of Protohaploxypinus spp. and Striatoabieites spp. In addition, the latter zone is, in the "Série de l'Agoula", immediately succeeded by a nonproductive interval, which compares well with the interval corresponding to the topmost section of Biozone KK 1, and to Biozone KK 2. Lastly, the uppermost assemblage P IV of the "Série de l'Agoula" can be correlated with Biozone KK 3 based on the common occurrence of Lueckisporites virkkiae and Platysaccus papilionis, which are characteristic species in both of the sections.

\section{Madagascar}

Palynological assemblages described by Wright \& Askin (1987) from Karoo sequences of the Morondava Basin in Madagascar indicate some comparable characteristics with the sequence at STRAT 1 borehole. The assemblage that characterizes the Lower Sakamena section of the Madagascar stratigraphy compares favourably with the assemblages at the top of Biozone KK 1, and in biozones KK 2 and KK 3 (Fig. 7). Taxa with closely comparable ranges of occurrence include Lueckisporites virkkiae, Striatopodocarpites pantii, Alisporites ovatus, Plicatipollenites gondwanensis, Protohaploxypinus limpidus, Platysaccus spp. and Weylandites spp.

\section{Correlation with other Gondwana regions}

Although long-distance (e.g., between continents) palynostratigraphic correlation is a common practice among biostratigraphers, there is always a great deal of uncertainty associated with the frequency of distribution and the palaeogeography of the respective palynomorphs. Firstly, the frequency distribution of taxa, even on a local scale, is greatly skewed such that there are major disparities between different sections under investigation (Agterberg \& Gradstein 1999), which ultimately gives rise to imprecise correlations. The extrapolation of such inherent problems to a large-scale or long-distance correlation is likely to result in exaggeration and mis-correlations. A common problem observed in the present study, but also reported by other workers (e.g., Souza 2006, Stephenson 2008), involves the realization that certain short-range taxa occur as long-range taxa in other regions, making correlation impractical. Secondly, studies have revealed that global floras progressively became palaeogeographically restricted, particularly during the latest Carboniferous to Permian, a phenomenon that has greatly reduced the efficacy of longdistance palynostratigraphic correlation (Playford \& Dino 2005). The above observations call for a concerted effort to upgrade and refine palynological data at the local level before attempting to erect long-distance correlation schemes. Therefore, with the above limitations in mind, the results from the present study will be compared and correlated with only a few selected Gondwana regions (e.g., Fig. 8).

\section{South America}

Correlation with the zonation scheme of Souza \& MarquesToigo (2003, 2005), and Souza (2006). - Palynological assemblages described by Souza and Marques-Toigo (2003, 2005) and Souza (2006), from the Brazilian Paraná Basin, indicate a remarkable similarity with the assemblages obtained from the Kalahari Karoo Basin in Botswana. Consequently, the palynozones erected for the sequence at STRAT 1 borehole can, to a certain degree, be compared and correlated (Fig. 8). The lowermost basal section of STRAT 1 (e.g., below Biozone KK 1) is poorly constrained but can be loosely correlated with the Crucisaccites monoletus Interval Zone on the basis of the common occurrence of monosaccates such as Cannanoropollis spp., Plicatipollenites spp., Potoniesporites spp., and Caheniasaccites spp. In addition, both azonotriletes spores (i.e. laevigate and apiculate), comprising Punctatisporites gretensis, Horriditriletes spp. etc., and zonolaminatitriletes (e.g., Cristatisporites spp. and Vallatisporites spp.) form significant constituents. The section of STRAT 1 borehole confined between the base of Biozone KK 1 and the lower section of Biozone KK 2 can be equated with the Vittatina costabilis Interval Zone on the basis of a significant incoming of several Vittatina species. In addition, the species after which the zone was named (e.g., Souza \& Marques-Toigo 2005, fig. 2f) also form a significant species in STRAT 1 (described as Vittatina sp. in this study). The top of Biozone KK 1 in STRAT 1 can be directly correlated with the top of the Protohaploxypinus goraiensis Subzone on the basis of the terminations of Plicatipollenites trigonalis and Potoniesporites congoensis. The upper sections of STRAT 1 borehole, stretching from the upper part of Biozone KK 2 up to and including Biozone KK 3, compares favourably with the Lueckisporites virkkiae Interval Zone. Taxa considered pertinent in recognizing the basal sections of the zones of correlation comprise Lueckisporites virkiae and Laevigatosporites spp. However, there are several other taxa characteristic of these zones, the most notable being: 
Marsupipollenites striatus, Striatopodocarpites fusus, Striatopodocarpites pantii and Weylandites lucifer.

\section{Australia}

Correlation with the zonation scheme of Backhouse (1991). - Backhouse (1991) established the most widely compared palynostratigraphic scheme from the Gondwana Permian sequences of the Collie Basin of Australia. There are however some difficulties in correlating the zonation scheme established here with that of Backhouse (1991) for the Collie Basin. The most important limitation is due to the fact that between the two areas certain key species reveal variable ranges and abundances, an observation also recognized by Backhouse (1991) when comparing the assemblages from the Collie Basin with other Australian basins. Due to the difficulties outlined above, only a broad correlation (Fig. 10), based on general similarities in the ranges of common taxa is considered here. The most closely comparable assemblages indicate a probable correlation of biozones KK 2 and KK 3 of STRAT 1 borehole with the Striatopodocarpites fusus Zone of the Collie Basin. The most significant taxa pertinent to this correlation comprise Florinites eremus, Horriditriletes tereteangulatus, Laevigatosporites vulgaris forma colliensis, Cycadopites cymbatus which disappears in KK 2, and Striatopodocarpites fusus, all of which are initiated at the same level in the Collie Basin. Other significant species that indicate a comparable range with Striatopodocarpites fusus in the Collie Basin, and also form characteristic taxa in the correlatable section of STRAT 1 borehole includes: Cymatiosphaera gondwanensis, Weylandites lucifer, Marsupipollenites triradiatus, Marsupipollenites striatus, Alisporites ovatus, Alisporites potoniei, Striatoabieites multistriatus and Protohaploxypinus limpidus. Based on the range of a few selected taxa, the lower part of the two cores, STRAT 1 and CKP 6, corresponding to KK 1 Biozone and the interval below, compares favourably with the section at Collie Basin that precedes the Striatopodocarpites fusus Zone, and includes the Pseudoreticulatispora pseudoreticulata Zone, the Pseudoreticulatispora confluens Zone and the top of Stage 2. The assemblage pertinent to this correlation includes: Plicatipollenites spp., Converrucosisporites naumoviae, Puncatisporites gretensis, Cycadopites cymbatus, Verrucosisporites andersonii and Cristatisporites spp.

\section{Antarctica}

Palynological studies undertaken by various workers in Antarctica reveal the occurrence of assemblages with common and comparable taxa to those recognized in this study. As a result, the sequence at STRAT 1 can be generally compared and broadly correlated with stratigraphic sections from Antarctica (Fig. 8). Permian assemblages described by Farabee et al. (1991), from the Buckley Formation of the central Transantarctic Mountains, closely compares with assemblages from the upper sections of STRAT 1 borehole, which comprises the upper part of Biozone KK 1, and biozones KK 2 and KK 3. The most characteristic taxa pertinent to this correlation include: Marsupipollenites triradiatus, Marsupipollenites striatus, Protohaploxypinus limpidus and Laevigatosporits spp. Lindström (1995a, b) also described some palynomorph assemblages from Antarctica which compare favourably with those recognized in the Karoo supergroup. The assemblages recognized from the Vestfjella mountainrange (e.g., Lindström 1995a) compare favourably with those obtained from the interval comprised of the upper part of Biozone KK 1 as well as biozones KK 2 and KK 3, as was the case with the Buckley Formation above (e.g., Farabee et al. 1991). The most significant taxa for comparison with the sequence at the Vestfjella mountain-range include: Alisporites ovatus, Alisporites potoniei, Cymatiosphaera gondwanensis, Florinites eremus, Laevigatosporites vulgaris, Lueckisporites spp., Marsupipollenites striatus, Marsupipollenites triradiatus, Striatopodocarpites fusus, Striatoabieites multistriatus, Weylandites lucifer and Weylandites magmus.

A comparison of the assemblages from STRAT 1 with those described by Lindström (1995b) from the Heimefrontfjella mountain-range reveals the occurence of two groups of correlatable taxa. Firstly, an older assemblage characterized by Cahenniasaccites ovatus, Cycadopites nevesi, Limitisporites rectus and Verrucosisporites andersonii, which broadly correlates the lower section of STRAT 1, i.e. the basal section of Biozone KK 1, with the lower half of Locality A. Secondly, a younger assemblage that correlates the upper part of Biozone KK 1 and biozones KK 2 and KK 3, with the upper half of Locality A (Lindström 1995b) is comprised of typical taxa as observed in the earlier sections above. Such taxa include: Alisporites ovatus, Alisporites potoniei, Laevigatosporites vulgaris, Protohaploxypinus limpidus, Striatopodocarpites fusus, Striatoabieites multistriatus and Weylandites magmus.

\section{Oman and Saudi Arabia}

Palynological studies from Oman and Saudi Arabia (e.g., Besems \& Schuurman 1987; Love 1994; Penney et al. 2008; Stephenson \& Osterloff 2002; Stephenson et al. 2003; Stephenson 2004, 2008) present an opportunity to compare and correlate the sequence in the Kalahari Karoo Basin with the Late Palaeozoic Gondwana sequence of the Arabian Peninsula. However, there is a lack of any significant similarities between taxa from either area, and hence only a limited comparative analysis that allows for only a broad and general correlation is possible. 
Benson N. Modie \& Alain Le Hérissé • Late Palaeozoic palynomorph assemblages from the Karoo Supergroup

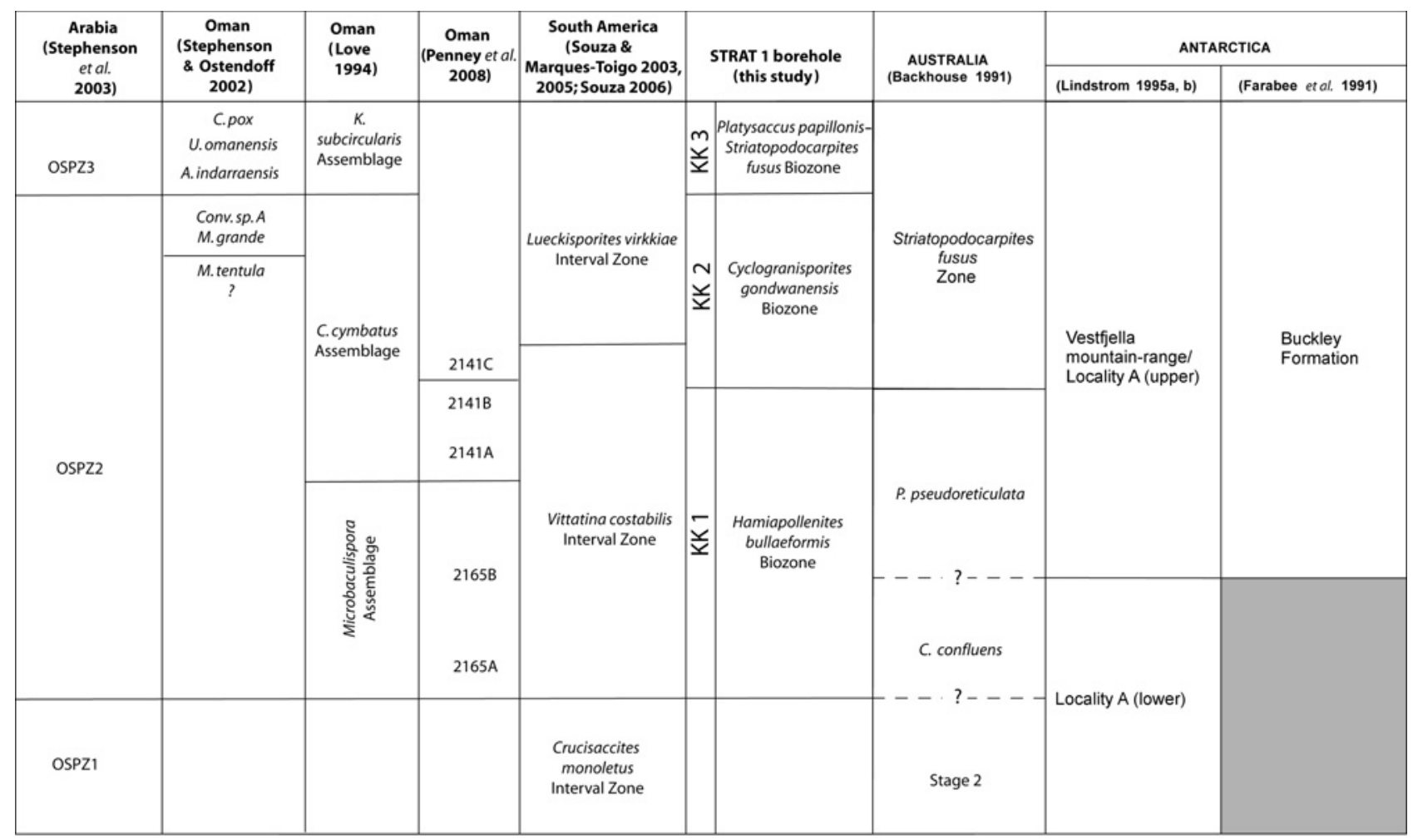

Figure 8. Correlation of STRAT 1 zonation scheme with main palynozonation for the regions of Gondwana.

Penney et al. (2008) proposed a complete correlation chart of palynostratigraphical schemes for Oman. The lower sections of STRAT 1 and CKP 6 boreholes, equivalent to KK 1 Biozone, can be broadly correlated with several assemblage zones defined in Oman and Saudi Arabia (Fig. 8): Besems \& Schuurman's (1987) Assemblage Group A; an equivalent of Love's (1994) Microbaculispora Assemblage; the succession of Penney et al.'s (2008) biozones 2165A and 2165B, and the base of Stephenson et al.'s (2003) OSPZ2 Biozone in Saudi Arabia. Those assemblages, as in the Karoo, are dominated by cingulocamerate trilete spores, such as Cristatisporites spp., and monosaccate pollen that includes Plicatipollenites spp. and Cannanoropollis spp. In Saudi Arabia, the base of OSPZ2 is defined by first occurrence of Horriditriletes spp., which are also well represented in the base of sequences of STRAT 1 and CKP 6.

Besems \& Schuurman's (1987) Assemblage Group B, which is characterized by striate and non-striate bisaccates, and Penney et al.'s (2008) biozones 2141A, 2141B and 2141C, can be broadly correlated with the upper part of Biozone KK 1 and part of Biozone KK 2.

Palynological assemblages from the Rahab and Lower Gharif members of the Aklata and Gharif formations, respectively, described by Stephenson \& Osterloff (2002) and Stephenson et al. (2003), can also be compared in a general and broad perspective. Taxa characteristic of the
Microbaculispora tentula and the Converrucosisporites sp. A - Microbaculispora grandegranulata biozones and top of Biozone OSPZ2, reveal close similarities to that characterising the upper part of Biozone KK 1 and Biozone KK 2. The most significant taxa pertinent to this comparison include: Apiculatisporis cornutus, Apiculatisporis leptoacaina, Apiculatisporis parmatus, Cycadopites cymbatus, Horriditriletes uruguaiensis, Pakhapites fusus and Verrucosisporites andersonii. The upper Biozone KK 3 of STRAT 1 and CKP 6 boreholes can be only poorly equated with the Alisporites indarraensis Biozone and the base of Stephenson et al.'s (2003) Biozone OSPZ3, based on a common increase in diversity of bisaccate pollen. Rare significant taxa pertinent to this correlation include Striatopodocarpites fusus and Protohaploxypinus limpidus.

\section{India}

Correlation with the Gondwana Sequence of India is overwhelmingly limited despite several decades of palynological studies that generated a plethora of data on morphotaxonomy and palynostratigraphy (e.g., Bharadwaj 1962, Bharadwaj \& Salujha 1964, Bharadwaj \& Srivastava 1969, Tiwari 1964, Kar 1968, Lele 1973, Tiwari \& Singh 1981, Tiwari \& Tripathi 1992, Singh et al. 1995, Meena 1999, Jana et al. 2002 etc.). Most palynostratig- 
raphic studies involve quantitative analyses at the genus level and describe assemblages that are confined to and based on the litho-stratigraphic subdivision, making it difficult to compare and correlate in terms of species ranges. In addition, there is some noticeable degree of variation in taxonomical nomenclature, which also contributes to the difficulties of correlation. Tiwari \& Tripathi (1992) compiled a species-determined composite palynozonation scheme based on stratigraphic distribution data obtained from previous studies undertaken in the Damodar Graben and several other pertinent basins of India. This work (i.e. Tiwari \& Tripathi 1992) allows for a limited but important comparative analysis of the assemblages from India and those recognized from the Kalahari Karoo Basin, as is described below.

A review of the ranges of common taxa reveals two groups of assemblages that broadly correlate the sequence at STRAT 1 borehole with the sequences in the Damodar-Rajmahal basins of India. The first group, comprising an older assemblage, is characterized by: Caheniasaccites ovatus, Cannanoropollis spp. (as Parasaccites), Plicatipollenites spp. (i.e. P. gondwanensis, P. densus, and P. trigonalis), and Potonieisporites spp., which closely correlates Biozone KK 1 with Tiwari \& Tripathi's (1992) assemblage zones I-III. This comparison broadly equates the Dwyka Group and the lowermost Ecca Group in STRAT 1 with the Talchir Formation of India.

The second group, which forms a younger assemblage and is relatively more diverse, is characterized by the following taxa: Alisporites ovatus (as Scheuringipollenites ovatus), Alisporites potoniei (as S. maximus), Laevigatosporites spp., Lophotriletes rectus, Marsupipollenties triradiatus, Marsupipollenites striatus, Protohaploxypinus limpidus (as Faunipollenites varius), Protohaploxypinus perexiguus (as F. perexiguus), and Weylandites lucifer. The latter assemblage favourably compares biozones KK 2 and KK 3, with Tiwari \& Tripathis's (1992) assemblage zones III-VIII. Such a comparison broadly correlates much of the Ecca Group in STRAT 1 section, with the Karharbari, Barakar and Kulti formations, as well as basal sections of the Raniganj Formation.

\section{Age deductions}

The subject of age determination on the basis of biostratigraphic character requires data of high density and quality the nature of which is beyond the scope of this study. Nevertheless, some general inferences can be made to give insight into chronostratigraphic relations. Age determination for biostratigraphic units depend on reliable correlation with marine sequences containing age-definitive faunas from which internationally agreed reference sections or stratotypes have been developed (Dunn 2001, Playford \& Dino 2005, Stephenson 2008). Most of the early reference sections used to erect international standard stages, with respect to the relative geological time-scale, developed in Europe, are largely based on the distribution of ammonoids, conodonts, and foraminifers (Christopher \& Goodman 1996). For most Gondwana sequences, where there is a general lack of marine fossils, zonation schemes are mainly based on terrestrial stratigraphic intervals, and precise dating and correlation remains uncertain. This is compounded by the geographic restriction of most Permian assemblages, which resulted from the existence of distinct palaeoclimatic zones with associated floral provinces (ECL 1990, Playford \& Dino 2005). In addition, radiometric age determination for Upper Palaeozoic strata of Gondwana, some of them for the South African Karoo Basin (e.g. Bangert et al. 1999), remain limited, and hence age control for the diagnostic assemblages remains equivocal. Consequently, age control for assemblages, and hence the zonation scheme, from the present study is inferred from comparison with other Gondwana palynofloras, and as a result remains tentative.

Comparison of the palynological assemblages from the poorly constrained basal sections of the Karoo sequence considered in this study, with other previous works (e.g., MacRae 1988, Dolby 1990, Souza 2006), indicate Late Carboniferous ages (i.e. Kasimovian-Gzhelian). The latter is seemingly typified, in Gondwana sequences, by the common dominance of monosaccates and trilete spores when compared with the dominance of bisaccate pollen (e.g., MacRae 1988, Souza 2006). Late Carboniferous ages have also been suggested from equivalent lithofacies (e.g.,

Figure 9. (Figs 9-11: Representative palynomorphs from the Lower Karoo sequence in STRAT 1 borehole. Slides are kept at the Laboratoire de Paléontologie, Université de Bretagne Occidentale, in Brest, France. Palynomorph locations on slides are recorded as England Finder (EF) coordinates.) Pollen and spores of the Platysaccus papilionis (A-F) and the Cyclogranisporites gondwanensis assemblage zones (G-O). $\bullet$ A - Lophotriletes rectus Bharadwaj \& Salujha, 1964 (slide: 1383, EF: J34). B - Vestigisporites ventrisaccatus Anderson, 1977 (slide: 1556, EF: W42.2). • C-Alisporites ovatus (Balme \& Hennelly) Jansonius, 1962 (slide: 1551, EF: O32.4). • D - Platysaccus papilionis Potonié \& Klaus, 1954 (slide: 1554, EF: E47). - E - Lueckisporites virkkiae Potonié \& Klaus, 1954 (slide: 1555, EF: E21). • F - Striatopodocarpites fusus (Balme \& Hennelly) Potonié, 1958 (slide: 1579, EF: V17.4). • G - Deltoidospora directa (Balme \& Hennelly) Norris, 1965 (slide: 1562, EF: C19.4). - H Cyclogranisporites gondwanensis Bharadwaj \& Salujha, 1964 (slide: 1599, EF: P39.3). I - Granulatisporites papillosus Hart, 1965 (slide: 1600, EF: U22.1). • J - Horriditriletes ramosus (Balme \& Hennelly) Bharadwaj \& Salujha, 1964 (slide: 1608, EF: T30.4). - K - Indotriradites australensis (Hart) Millsteed, 1999 (slide: 1578, EF: P24.2). $・$ L - Lundbladispora braziliensa (Pant \& Srivastava) emend. Marques-Toigo \& Picarelli, 1984 (slide: 1599, EF: K42). M - Alisporites potoniei (Lakhanpal, Sah \& Dube) Somers, 1968 (slide: 1551, EF: O32.4). N - Protohaploxypinus limpidus (Balme \& Hennelly) Balme \& Playford, 1967 (slide: 1562, EF: P24.4). • O - Striatopodocarpites cancellatus (Balme \& Hennelly) Hart, 1963 (slide: 1578, EF: Q22). Scale bar corresponds to 10 $\mu$ m. 
Benson N. Modie \& Alain Le Hérissé • Late Palaeozoic palynomorph assemblages from the Karoo Supergroup


(

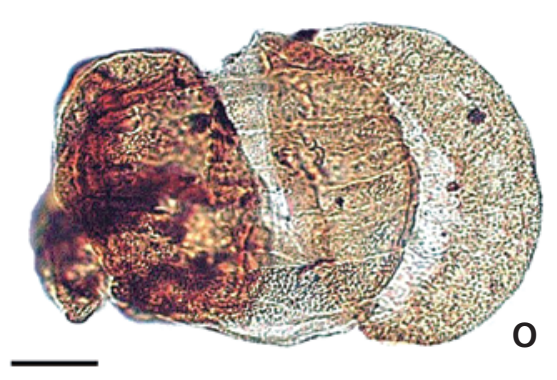





Figure 10. Pollen and spores of the Hamiapollenites bullaeformis Assemblage Zone. • A - Punctatisporites gracilis Anderson, 1977 (slide: 1602 , EF: H47.1). B - Retusotriletes diversiformis (Balme \& Hennelly) Balme \& Playford, 1967 (slide: 1603, EF: S20.1). $\bullet$ C - Lophotriletes rarus Bharadwaj \& Salujha, 1964 (slide: 1619, EF: F37). D - Cristatisporites microvacuolatus (Dias-Fabrício) emend. Picarelli \& Dias-Fabrício, 1990 (slide: 1598 , EF: D39.3). E - Raistrickia crenata Foster, 1979 (slide: 1627, EF: N37.4). - F - Cristatisporites morungavensis (Dias-Fabrício) emend. Picarelli \& Dias-Fabrício, 1990 (slide: 1622, EF: J31.2) • G - Densosporites rotundus Falcon, 1978 (slide: 1581, EF: R21.4). H - Weylandites magmus (Bose \& Kar) Backhouse, 1991 (slide: 1563, EF: V30.3). I - Limitisporites rectus Leschik, 1956 (slide: 1571, EF: T24). J - Apiculatisporis parmatus (Balme \& Hennelly) comb. nov. (slide: 1603, EF: V49.3). - K - Vittatina scutata (Balme \& Hennelly) Bharadwaj, 1962 (slide: 1565, EF: Q23). - L - Hamiapollenites bullaeformis (Samoilovich) Jansonius, 1962 (slide: 1623, EF: T35.4). Scale bar corresponds to $10 \mu \mathrm{m}$.

Dwyka Group), by Key et al. (1995) based on studies from southwest Botswana, as well as Visser (1990) who studied glacigene deposits from southern Africa. Souza (2006) gives a brief account of limited radiometric ages from the Dwyka Group, which also indicates late Carboniferous stages.

Preliminary correlation of the biozones from STRAT 1 and CKP 6 with other relevant palynological studies from Gondwana sequences (e.g., Wright \& Askin 1987; ECL 1990; Hankel 1992; Farabee et al. 1991; Lindström 1995a, b; Souza 2006) generally reveal an Early Permian age for Biozone KK 1, whereas the biozones KK 2 and KK 3 are of late early Permian to early Middle Permian age. There are, however, difficulties in defining stage boundaries, which requires more refined data to allow direct correlation at short stratigraphic intervals. Nevertheless, tentative age in- ferences for the present zonation scheme from the Kalahari Karoo Basin are made based on comparison with the zonation schemes for the Paraná Basin of Brazil in South America (e.g., Di Pasquo et al. 2003a, b; Souza \& Marques-Toigo 2003, 2005; Souza 2006), and their calibration by radiometric dates (Santos et al. 2006, Stephenson 2008). It is also worth noting that the similarities indicated by the assemblage taxa from the Kalahari Karoo Basin and the Paraná Basin are also corroborated by the palaeogeographic similarities of the two basins as reflected by several illustrations of their Late Palaeozoic reconstruction (e.g., Kalkreuth et al. 1999, Turner 1999, Wopfner 1999, Golonka \& Ford 2000 etc.).

As described earlier, the KK 1 Biozone globally correlates with the Vittatina costabilis Interval Zone (Souza 

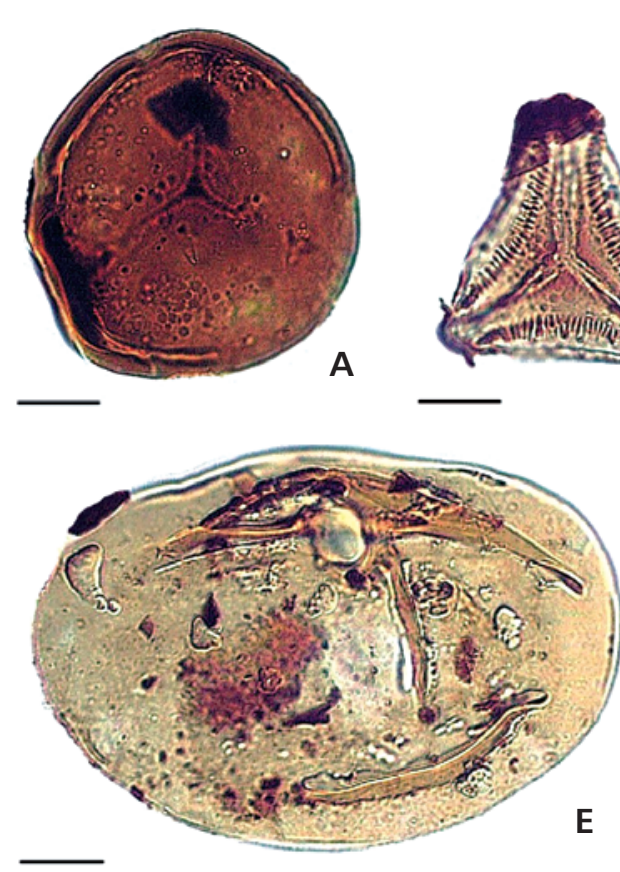

$\mathrm{E}$

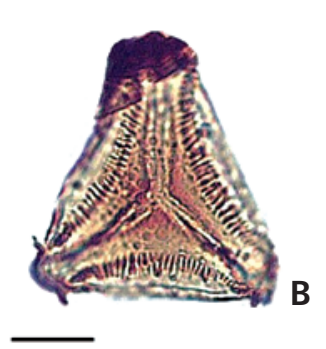

.
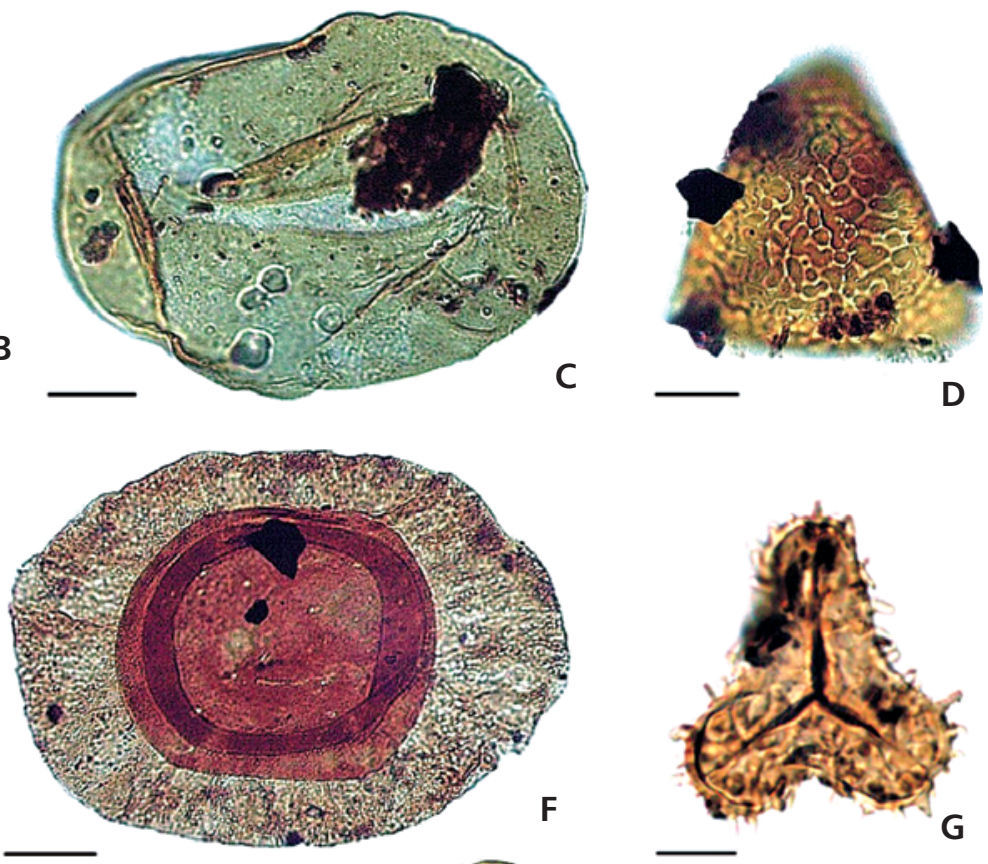

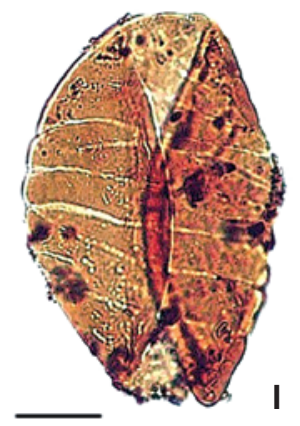



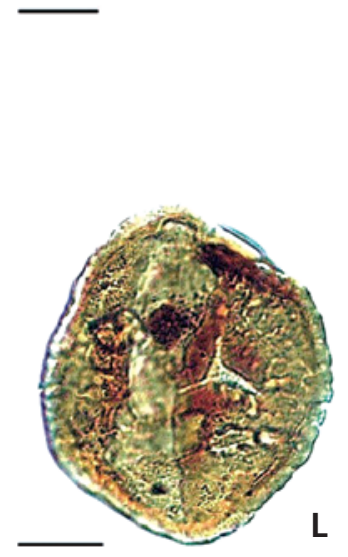

Figure 11. A selected few significant pollen and spores used to determine the range zones for STRAT 1 and CKP6 boreholes. • A - Punctatisporites ubischii Foster, 1979 comb. nov. (slide: 1571, EF: T47.4). B - Cirrabaculisporites lageniformis (Anderson) comb. nov. (slide: 1564, EF: K38.3). - C - Laevigatosporites vulgaris (Ibrahim) Ibrahim, 1933 (slide: 1580, EF: G33). D - Converrucosisporites irregularis (Anderson) comb. nov. (slide: 1643, EF: U43.3). • E - Laevigatosporites plicatus Kar, 1968 (slide: 1561, EF: T30.3). • F - Potonieisporites congoensis Bose \& Maheshwari, 1968 (slide: 1629, EF: K17.2). $\bullet \mathrm{G}$ - Horriditriletes gondwanensis (Tiwari \& Moiz) Foster, 1975 (1580, EF: E19). • H - Vittatina sp. (slide: 1621, EF: Y26.2). - I - Pakhapites fusus (Bose \& Kar) Menéndez, 1971(slide: 1613, EF: W37.1). J - Divaricrassus minor (Anderson) Millsteed, 1999 (slide: 1599, EF: R22.4). $・$ K - Weylandites lucifer (Bharadwaj \& Salujha) Foster, 1975 (slide: 1558, EF: O37.1). $\bullet$ - Marsupipollenites triradiatus Balme \& Hennelly, 1956 (slide: 1559, EF: M44.1). Scale bar corresponds to $10 \mu \mathrm{m}$ (except for Fig. 11F where the scale bar represents $20 \mu \mathrm{m}$ ).

2006). From the latter correlation, Early Permian age ranging from the Asselian stage to the Artinskian stage are deduced. The upper part of KK 1 Biozone plus KK 2 and KK 3 biozones generally correlate with the Lueckisporites virkkiae Interval Zone (Souza 2006), and in the Parana Basin, Shrimp U-Pb zircon dating of the Irati Formation revealed an age of $278.4 \mathrm{Ma}$ (Artinskian; Gradstein et al. 2004) for the base of the Luekisporites virkkiae Zone (Santos et al. 2006). Consequently, a tentative late Early Permian to earliest Middle Permian age range is proposed for the upper biozones KK 2 and KK 3 . A rare absolute age of $270 \mathrm{Ma}$ reported from the Collingham Formation of
South Africa (e.g., Turner 1999), which overlies the Whitehill Formation, supports a late Early Permian age (i.e. Kungurian) for the uppermost part of Biozone KK 2. The latter represent a lithofacies section indicated in Johnson et al. (1996) to immediately overlie the Whitehill Formation in the Kalahari Karoo Basin and, hence probably equates with the Collingham Formation. Comparisons of the assemblage characteristic of Biozone KK 3 with several regional and Gondwana-wide studies indicates Middle Permian (Guadalupian) ages (e.g., Wright \& Askin 1987, Farabee et al. 1991, Hankel 1992, Lindström 1995a). As discussed above, the top of Biozone KK 2, is considered to 
represent late Early Permian age, therefore, the succeeding Biozone KK 3 is considered to represent early Middle Permian ages (i.e. Roadian). Consequently, the base of Biozone KK 3 is tentatively equated with the boundary between Early and Middle Permian for the sequence at STRAT 1 borehole in the Kalahari Karoo Basin.

\section{Conclusions}

The Lower Karoo sequence of the Karoo Supergroup in the Kalahari Karoo Basin contains relatively well preserved pollen and spore palynomorphs suitable for biostratigraphic classifications. Taxa range analysis, determined on the basis of first and last occurrences datum, revealed the occurrence of long, medium, and short range species, which allowed for the subsequent erection of biostratigraphic units or biozones. Three assemblage zones have been erected for each of the study sections i.e. STRAT 1 and CKP 6 boreholes. Although there appears to be considerable variation in taxa ranges between the sections considered, the frequent occurrence of common events nevertheless highlights great potential for palynological comparisons. A preliminary direct correlation between STRAT 1 and CKP 6 borehole sections is attainable on the basis of the three assemblage zones which are common to both sections. The assemblage zones erected are comprised of, in ascending order of stratigraphy, the Hamiapollenites bullaeformis Assemblage Zone (Biozone KK 1), the Cyclogranisporites gondwanensis Assemblage Zone (Biozone KK 2), and the Platysaccus papilionis-Striatopodocarpites fusus Assemblage Zone (Biozone KK 3). Only limited comparisons and broad correlations with other local previous palynology studies have been established, owing to the non-availability of taxa range data in most such studies. Comparison and tentative correlation of the zones with similar zones erected in the region, as well as Gondwana-wide, have been established, albeit cautiously, in recognition of several limiting factors that commonly hamper long-distance correlations. Amongst the notable limiting factors is the disparity in the frequency distribution of taxa between sections, also relatively common in local correlations, as well as factors of global scale such as palaeogeographic restriction of flora or provincialism, which is considered to have been well established during the latest Carboniferous to Permian times. Generally, there appears to be a closer degree of similarity between assemblages from the Paraná Basin of South America and those from the Kalahari Karoo Basin. Age control for the zonation schemes erected in this study is inferred from comparison with similar assemblages from previous Gondwana studies, and hence remains tentative. The overall age range is from the Late Carboniferous (Kasimovian-Gzhelian) to the latest Early or possibly earliest Middle Permian (Late Cisularian to Early Guadalupian).

\section{Acknowledgements}

This paper is published with the permission of the Director of the Department of Geological Survey, Botswana. It is part of a Ph.D. study prepared under the guidance of A. Le Hérissé, Université de Brest, France. B. Modie wish to extend his gratitude to J.-J. Tiercelin and B. Le Gall, also of the Université de Brest, who provided assistance and helpful discussions during the study, but most importantly played a pivotal role in initiating collaboration between the Botswana Department of Geological Survey and the Université de Brest. Many thanks go to M.H. Stephenson of the British Geological Survey (Keyworth, U.K.), J. Broutin of the University of Paris (Jussieu), and B.D. Millsteed, then of the University of Durban-Westville (Durban, South Africa), all of whom provided valuable comments, suggestions, and assistance during the course of the study. F. Paris and R. Brocke are also thanked for their helpful comments on the earlier version of the manuscript.

\section{References}

AGTERBERG, F.P. \& GRADSTEIN, F.M. 1999. The RASC method of ranking and scaling of biostratigraphic events. Earth-Science Reviews 46, 1-25. DOI 10.1016/S0012-8252(99)00007-0

AITKEN, G.A. 1994. Permian palynomorphs from the number 5 seam, Ecca Group, Witbank/Highveld coalfields, South Africa. Palaeontologia africana 31, 97-109.

ANDERSON, J.M. 1977. The Biostratigraphy of the Permian and Triassic. Part 3: A review of Gondwana Permian palynology with particular reference to the northern Karoo Basin, South Africa. Memoir, Botanical Survey South Africa 41.

BACKHOUSE, J. 1991. Permian palynostratigraphy of the Collie Basin, Western Australia. Review of Palaeobotany and Palynology 67, 237-314. DOI 10.1016/0034-6667(91)90046-6

BANGerT, B., STOLHOFEn, H., LORENZ, V. \& ARMSTRONG, R. 1999. The geochronology and significance of ash-fall tuffs in the glaciogenic Carboniferous-Permian Dwyka Group OF Namibia and South Africa. Journal of African Earth Science 29, 33-49. DOI 10.1016/S0899-5362(99)00078-0

BESEMS, R.E. \& SCHUURMAN, W.M.L. 1987. Palynostratigraphy of Late Paleozoic glacial deposits of the Arabian peninsular with special reference to Oman. Palynology 11, 37-53.

BHARADWAJ, D.C. 1962. The miospore genera in the coals of Raniganj Stage (Upper Permian), India. The Palaeobotanist 9 , 68-106.

BHARADWAJ, D.C. \& SALUJHA, S.K. 1964. Sporological study of seam VIII in Raniganj Coalfield, Bihar (India). Part 1 - Description of sporae dispersae. The Palaeobotanist 12, 181-215.

BharadwaJ, D.C. \& SRIVASTAVA, S.C. 1969. Some new miospores from Barakar Stage Lower Gondwana, India. The Palaeobotanist 17, 220-229.

CADMAN, C. 1995. Report on samples submitted for palynological analysis from Botswana Karoo boreholes. 7 pp. Bernard Price Institute of Palaeontology, Johannesburg.

CARNEY, J., ALDISS, D.T. \& LOCK, N.P. 1994. The geology of Botswana. Bulletin of the Geological Survey of Botswana 37, 1-113.

Christopher, R.A. \& GOODMAN, D.K. 1996. Introduction to biostratigraphy and time scales. In JANSONIUS, J. \& 
MCGREGOR, D.C. (eds) Palynology: principles and applications. American Association of Stratigraphic Palynologists Foundation 2, 463-492.

Cox, K.G. 1992. Karoo igneous activity, and the early stages of the break-up of Gondwanaland. In STOREY, B.C., ALABASTER, T. \& PANKHURST, R.J. (eds) Magmatism and the Causes of Continental Break-up. Geological Society Special Publication 68, 137-148.

DALY, M.C., LAWREnCE, S.R., Kimun'A, D. \& Binga, M. 1991. Late Palaeozoic deformation in central Africa: a result of distant collision? Nature 350, 605-607. DO1 10.1038/350605a0

DAVISON, G.E. \& STEENKAMP, W.H.B. 1995. Kalahari Gold Seismic survey interpretation of the Karoo Supergroup. Internal Report, Geological Survey Botswana, CR5/3/13.

D'ENGELBRONNER, E.R. 1996. New palynological data from Karoo sediments, Mana Pools basin, northern Zimbabwe. Journal of African Earth Sciences 23, 1, 17-30. DOI 10.1016/S0899-5362(96)00049-8

DI PASQUO, M., AZCUY, C.L. \& SouZA, P.A. 2003a. Palinología del Carbonífero Superior del Subgrupo Itararé en Itaporanga, Cuenca Paraná, Estado de São Paulo, Brasil. Parte 1: Sistemática de esporas y paleofitoplancton. Ameghiniana 40(3), 277-296.

Di PAsquO, M., AzCuY, C.L. \& SouZA, P.A. 2003b. Palinología del Carbonífero Superior del Subgrupo Itararé en Itaporanga, Cuenca Paraná, Estado de São Paulo, Brasil. Parte 2: Sistemática de polen y significado paleoambiental y estratigráfico. Ameghiniana 40(3), 297-313.

DolBY, G. 1990. The biostratigraphy of the G.S.D./P.C.I.A.C Masetheng Pan-1 well, Botswana. 23 pp. Geological Survey of Botswana.

DunN, M.T. 2001. Palynology of the Carboniferous-Permian boundary stratotype, Aidaralash Creek, Kazakhstan. Review of Palaeobotany and Palynology 116, 175-194.

DOI 10.1016/S0034-6667(01)00093-8

EXPlORATION CONSUltants LtD. 1990. Pan African Basin Study. Geological Survey Botswana.

ExPloRATION CONSUltanTS LTD. 1998. Petroleum Potential of the Karoo of Botswana. Volume 1 - Report GC 122/2/la. Geological Survey of Botswana.

FALCON, R. 1975. Palyno-stratigraphy of the Lower Karroo sequence in the central Sebungwe District, Mid-Zambezi Basin, Rhodesia. Palaeontologia africana, 18, 1-29.

FALCON, R. 1978. New Permian miospores from Rhodesia. Arnoldia Rhodesia 8, 24, 1-32.

FARABEE, M.J., TAYLOR, E.L. \& TAYLOR, T.N. 1991. Late Permian palynomorphs from the Buckley Formation, central Transantarctic Mountains, Antarctica. Review of Palaeobotany and Palynology 69, 353-368.

DOI $10.1016 / 0034-6667(91) 90037-4$

GOLONKA, J. \& FORD, D. 2000. Pangean (Late Carboniferous-Middle Jurassic) palaeoenvironmental and lithofacies. $P a$ laeogeography, Palaeoclimatology, Palaeoecology 161, 1-34. DOI 10.1016/S0031-0182(00)00115-2

Gradstein, F.M., OGG, J.G., AGTERBERG, F.P., BlEEKER, W., COOPER, R.A., DAVydov, V., GibBARD, P., HinnOV, L.A., HOUSE, M.R., LOURENS, L., LUTERBACHER, H.P., McArthur, J., Melchin, M.J., RobB, I.J., Shergold, J., VilleneuVe, M., WARDLAW, B.R., Ali, J., BRINKHUIS, H., Hilgen, F.J., HoOKer, J., Howarth, R.J., KNOll, A.H.,
LASkar, J., MONEChi, S., Plumb, K.A., POWEll, J., RAFFi, I., RÖHL, A.H., SADler, P., SANFILIPPO, A., SCHITZ, B., Shackleton, N.J., ShiEldS, G.A., STRAuss, H., VAN DAM, J., VAN Kolfschoten, T., VeIZER, I. \& WiLSON, D. 2004. A geologic TimeScale 2004. 589 pp. Cambridge, Cambridge University Press.

GreEn, D., Crockett, R.N. \& JonES, M.T. 1980. Tectonic control of Karoo sedimentation in mid-eastern Botswana. Transactions Geological Society South Africa 83, 213-219.

HANKel, O. 1992. Late Permian to Early Triassic microfloral assemblages from the Maji ya Chumvi Formation, Kenya. Review of Palaeobotany and Palynology 72, 129-147.

DOI 10.1016/0034-6667(92)90181-F

HANKEL, O. 1993. Early Triassic plant microfossils from Sakamena sediments of the Majunga Basin, Madagascar. Review of Palaeobotany and Palynology 77, 213-233.

DOI 10.1016/0034-6667(93)90005-F

JANA, B.N., BHATTACHARYYA, A.P. \& CHAKRABORTI, B. 2002. Permian Palynological Succession from Mand - Raigarh Coalfield, Chhattisgarh. Journal of the Geological Society of India $59,537-546$.

JARDINE, S. 1974. Microflores des formations du Gabon attribuées au Karroo (Microfloras from formations in Gabon attributed to the Karroo). Review of Palaeobotany and Palynology 17, 75-112. DOI 10.1016/0034-6667(74)90093-1

JOHNSON, M.R., VAN VUUREN, C.J., HEGENBERGER, W.F., KEY, R. \& SHOKO, U. 1996. Stratigraphy of the Karoo Supergroup in southern Africa: an overview. Journal of African Earth Sciences 23(1), 3-15. DO1 10.1016/S0899-5362(96)00048-6

Jourdan, F., Feraud, G., Bertrand, H., KAmpunZu, A.B., Tshoso, G. \& LE GALL, B. 2005. The Karoo Large Igneous Province: brevity, origin and relation with mass extinction in question from new ${ }^{40} \mathrm{Ar} /{ }^{39} \mathrm{Ar}$ age data. Geology 33, 745-748. DOI 10.1130/G21632.1

Kalkreuth, W., Holz, M., CAZzulo-Klepzig, M., MARQues-Toigo, M., UtTing, J. \& SEMKIVA, P. 1999. A comparative study of the geology, petrology and palynology of Permian coals in Tanzania and southern Brazil. Journal of African Earth Sciences 29(1), 91-104.

DOI 10.1016/S0899-5362(99)00082-2

KAR, R.K. 1968. Palynology of the Barren Measures sequence from Jharia Coalfield, Bihar, India. 2. General palynology. The Palaeobotanist 16(2), 115-140.

Keyey, R.M., McGeorge, I., AitKen, G., CAdman, A., Tidi, J. \& ANSCOMBE, J. 1995. The Karoo supergroup of south-west Botswana; new detailed information on the Dwyka and Ecca groups. Centennial Geocongress Extended Abstracts, Geological Society South Africa, 781-784.

LELE, K.M. 1973. Studies in the Talchir flora of India - 10. Early and late Talchir microfloras from the West Bokaro Coalfield, Bihar. The Palaeobotanist 22(3), 219-235.

LINDSTRÖM, S. 1995a. Early Late Permian palynostratigraphy and palaeo-biogeography of Vestfjella, Dronning Maud Land, Antarctica. Review of Palaeobotany and Palynology 86, 157-173. DOI $10.1016 / 0034-6667(94) 00104-R$

LINDSTRÖM, S. 1995b. Early Permian playnostratigraphy of the northern Heimefrontfjella mountain-range, Dronning Maud Land, Antarctica. Review of Palaeobotany and Palynology 89, 359-415. DOI 10.1016/0034-6667(95)00058-3 
MACRAE, C.S. 1978. Palaeozoic palynology of Botswana. 98 pp. M.Sc. thesis, Witwatersrand University, Johannesburg, South Africa.

MACRAE, C.S. 1988. Palynostratigraphic correlation between the Lower Karoo sequence of the Waterberg and Pafuri coal-bearing basins and the Hammanskraal plant macrofossil locality, Republic of South Africa. Geological Survey Memoir 75, 1-217.

MANUM, S.B. \& TIEN, N.D. 1973. Palyno-stratigraphy of the Ketewaka Coalfield (Lower Permian), Tanzania. Review of Palaeobotany and Palynology 16, 213-227. DOI 10.1016/0034-6667(73)90020-1

MARQues-Toigo, M. \& KlePZiG, M.C. 1995. Catálogo de Esporos e Pólen fósseis do Paleozóico. Boletim de Geociências da Petrobras 1(9), 1-151.

MEENA, K.L. 1999. Palynostratigraphic studies of sub-surface Raniganj - Barren Measures sediments from Mand-Raigarh Coalfield, Son-Mahanadi, Madhya Pradesh, India. The Palaeobotanist 48, 214-224.

Miall, A.D. 1990. Principles of Sedimentary Basin Analysis. $2^{\text {nd }}$ edition. 668 pp. Springer-Verlag, New York.

MiLLSTEED, B.D. 1994. Palynological evidence for the age of the Permian Karoo coal deposits near Vereeniging, northern Orange Free State, South Africa. South African Journal of Geology 97, $1,15-20$.

MiLlsteED, B.D. 1999. Palynology of the Early Permian coalbearing deposits near Vereeniging, Free State, South Africa. Bulletin of the Council for Geoscience 124, 1-81.

ModIE, B.N. 2007. The Palaeozoic palynostratigraphy of the Karoo Supergroup and Palynofacies insight into palaeoenvironmental interpretations, Kalahari Karoo Basin, Botswana. 301 pp. Ph.D. thesis, Université de Bretagne Occidentale, Brest.

NyAmBe, I.A. \& UtTING, J. 1997. Stratigraphy and palynostratigraphy, Karoo Supergroup (Permian and Triassic), mid-Zambezi Valley, southern Zambia. Journal of African Earth Sciences 24(4), 563-583. DOI 10.1016/S0899-5362(97)00081-X

PENNEY, R.A., Al BARRAM, I. \& STEPHENSON, M.H. 2008. A high resolution palynozonation for the Al Khlata Formation (Penssylvanian to Lower Permian) South Oman. Palynology 32, 213-229. DOI 10.2113/gspalynol.32.1.213

PlaYFord, G. \& DiNO, R. 2005. Carboniferous and Permian palynostratigraphy, 101-121. In KouTsouKos, E.A.M. (ed.) Applied Stratigraphy. Springer, Dordrecht. DOI 10.1007/1-4020-2763-X_5

READING, H.G. 1986. Sedimentary Environments and Facies. 615 pp. Blackwell, London.

Santos, R.V., Souza, P.A., Souza De Alvarenga, C.J., DANTAS, E.L., Pimentel, M.M., Gouveia De OliVEIRA, C. \& MEdeIRos DE ARAUJO, L. 2006. SHRIMP U-Pb zircon dating and palynology of bentonite layers from the Permian Irati Formation, Paraná Basin, Brazil. Gondwana Research 9, 456-463. DO] 10.1016/j.gr.2005.12.001

Semkiva, P., Kalkreuth, W., Utting, J., Mpanju, F. \& HAGEMANN, H. 2003. The geology, petrology, palynology and geochemistry of Permian coal basins in Tanzania: 2. Songwe-Kiwira Coalfield. International Journal of Coal Geology 55, 157-186. DOI 10.1016/S0166-5162(03)00108-3

SINGH, T., TIWARI, R.S. \& VIJAYA, AWATAR-RAM 1995. Stratigraphy and palynology of Carboniferous-Permian-Triassic suc- cession in Spiti Valley, Tethys Himalaya, India. Journal of the Palaeontological Society of India 40, 55-76.

SMITH, R.A. 1984. The lithostratigraphy of the Karoo Supergroup in Botswana. Bulletin of the Geological Survey of Botswana 26, $1-239$.

SMITH, R.M.H., ERIKSSON, P.G. \& BOTHA, W.J. 1993. A review of the stratigraphy and sedimentary environments of the Karooaged basins of Southern Africa. Journal of African Earth Sciences 16, 143-169.

DO1 10.1016/0899-5362(93)90164-L

SouZA, P.A. 2006. Late Carboniferous palynostratigraphy of the Itararé Subgroup, northeastern Paraná Basin, Brazil. Review of Palaeobotany and Palynology 138, 9-29.

DOI 10.1016/j.revpalbo.2005.09.004

SoUZA, P.A. \& MARQues-Toigo, M. 2003. An overview on the Palynostratigraphy of the Upper Paleozoic strata of the Brazilian Paraná Basin. Revista del Museo Argentino de Ciencias Naturales 5(2), 205-214.

SouZA, P.A. \& MArques-Toigo, M. 2005. Progress on the palynostratigraphy of the Permian strata in Rio Grande do Sul State, Paraná Basin, Brazil. Annals of the Brazilian Academy of Sciences 77(2), 353-365.

STEPHENSON, M.H. 2008. A review of the palynostratigraphy of Gondwanan Late Carboniferous to early Permian glacigene successions, 317-330. In FIELDING, C.R., FRANK, T.D. \& ISBELL, J.L. (eds) Resolving the Late Paleozic Ice Age in Time and Space. Geological Society of America Special Paper 441.

STEPHENSON, M.H. \& MCLEAN, D. 1999. International correlation of Early Permian palynofloras from the Karoo sediments of Morupule, Botswana. South African Journal Geology 102(1), 3-14.

THOMAS, D.S.G. \& SHAW, P.A. 1991. The Kalahari Environment. 284 pp. Cambridge University Press, Cambridge.

Thomas, R.J., MARshall, G.G.A., Du Plessis, A., MiLler, J.A., FITCH, F.J., VON BRUNN, V. \& WATKEYS, M.K. 1992. Geological studies in southern Natal and Transkei: implications for the Cape Orogen, 229-236. In DE WIT, M.J. \& RANSOME, I.G.D. (eds) Inversion Tectonics of the Cape Foldf Belt, Karoo and Cretaceous Basins od Southern Africa. Balkema, Rotterdam.

TIWARI, R.S. \& SINGH, V. 1981. Morphographic study of some dispersed trilete miospores (Sub-infraturma-Varitrileti) from the Lower Gondwana of India. The Palaeobotanist 27(3), 253-296.

TIWARI, R.S. \& TRIPATHI, A. 1992. Marker Assemblage-Zones of spores and pollen species through Gondwana Palaeozoic and Mesozoic sequence in India. The Palaeobotanist 40, 194-236.

TSCHUDY, R.H. \& KoSANKE, R.M. 1966. Early Permian vesiculate pollen from Texas, USA. The Palaeobotanist 15, 59-71.

TURNER, B.R. 1999. Tectonostratigraphical development of the Upper Karoo foreland basin: orogenic unloading versus thermally-induced Gondwana rifting. Journal of African Earth Sciences 28, 215-238. DOI 10.1016/S0899-5362(99)00025-1

UtTING, J. 1976. Pollen and Spore assemblages in the Luwumbu Coal Formation (Lower Karroo) of the north Luangwa Valley, Zambia, and their biostratigraphic significance. Review of Palaeobotany and Palynology 21, 295-315. DOI 10.1016/0034-6667(76)90044-0

VISSER, J.N.J. 1990. The age of the late Palaeozoic glacigene deposits in southern Africa. South African Journal of Geology 93(2), 366-375. 
WoOD, G.D., Gabriel, A.M. \& LAWSON, J.C. 1996. Chapter 3. Palynological techniques - processing and microscopy. In JANSONIUS, J. \& MCGREGOR, D.C. (eds) Palynology: principles and applications. American Association of Stratigraphic Palynologists Foundation 1, 29-50.

WOPFNER, H. 1999. The Early Permian deglaciation event between
East Africa and northwestern Australia. Journal of African Earth Sciences 29(1), 77-90. DOI 10.1016/S0899-5362(99)00081-0

Wright, R.P. \& ASKIN, R.A. 1987. The Permian-Triassic boundary in the southern Morondava Basin of Madagascar as defined by plant microfossils. American Geophysical Union, Geophysical Monograph 41, 157-166.

\section{APPENDIX I - SPECIES INDEX, SPORES, POLLEN, ACRITARCHS AND CHLOROPHYCEAN ALGAE IDENTIFIED IN THIS STUDY}

1. Calamospora aplata Bharadwaj \& Salujha, 1964

2. Concavisporites mortonii (de Jersey) de Jersey, 1962

3. Concavisporites sp.

4. Deltoidospora directa (Balme \& Hennelly) Norris, 1965

5. Pachytriletes splendens (Saksena) Millsteed, 1999

6. Punctatisporites gretensis Balme \& Hennelly 1956

7. Punctatisporites gracilis Anderson, 1977

8. Punctatisporites parvus Anderson, 1977

9. Punctatisporites ubischii Foster 1979 comb. nov.

10. Punctatisporites sp.

11. Retusotriletes diversiformis (Balme \& Hennelly) Balme \& Playford, 1967

12. Retusotriletes golatensis Staplin, 1960

13. Cyclogranisporites gondwanensis Bharadwaj \& Salujha, 1964

14. Cyclogranisporites sp.

15. Granulatisporites papillosus Hart, 1965

16. Granulatisporites angularis (Staplin) Ybert, 1975

17. Granulatisporites trisinus Balme \& Hennelly, 1956

18. Granulatisporites sp.

19. Granulatisporites sp. A

20. Anacanthotriletes sp.

21. Anacanthotriletes sp. A

22. Apiculatisporis cornutus (Balme \& Hennelly) Høeg \& Bose, 1960

23. Apiculatisporis unicus (Tiwari) Bharadwaj \& Srivastava comb. nov.

24. Apiculatisporis levis (Balme \& Hennelly) Segroves, 1970

25. Apiculatisporis leptoacaina (Jones \& Truswell) comb. nov.

26. Apiculatisporis parmatus (Balme \& Hennelly) comb. nov.

27. Didecitriletes eoericiana (Anderson) Millsteed, 1999

28. Didecitriletes ericianus (Venkatachala \& Kar, 1965)

29. Divaricrassus minor (Anderson) Millsteed, 1999

30. Lophotriletes rectus Bharadwaj \& Salujha, 1964

31. Lophotriletes novicus Singh, 1964

32. Lophotriletes rarus Bharadwaj \& Salujha, 1964

33. Lophotriletes sp.

34. Lophotriletes sp. A

35. Cirrabaculisporites lageniformis (Anderson) comb. nov.

36. Cirrabaculisporites plumsteadi (Hart) Anderson comb. nov.

37. Cirrabaculisporites ramosus Maheshwari \& Bose, 1969

38. Cirrabaculisporites sp.

39. Horriditriletes brevis Bharadwaj \& Salujah, 1964

40. Horriditriletes ramosus (Balme \& Hennelly) Bharadwaj \& Salujha, 1964

41. Horriditriletes tereteangulatus (Balme \& Hennelly) Backhouse, 1991
42. Horriditriletes uruguaiensis (Marques-Toigo) Archangelsky \& Gamerro, 1979

43. Horriditriletes curvibaculosus Bharadwaj \& Salujha, 1964

44. Horriditriletes gondwanensis (Tiwari \& Moiz) Foster, 1975

45. Horriditriletes sp.

46. Horriditriletes sp. A

47. Raistrickia crenata Foster, 1979

48. Converrucosisporites naumoviae (Hart) Backhouse, 1991

49. Converrucosisporites pseudoreticulatus (Balme \& Hennelly) comb. nov.

50. Converrucosisporites irregularis (Anderson) comb. nov.

51. Converrucosisporites $\mathrm{sp}$.

52. Converrucosisporites sp. A

53. Verrucosisporites morulatus (Knox) emend. Smith \& Butterworth, 1967

54. Verrucosisporites andersonii (Anderson) Backhouse, 1988

55. Verrucosisporites trisecatus Balme \& Hennelly, 1956

56. Verrucosisporites sp.

57. Verrucosisporites sp. A

58. Convolutispora intrareticulata (Anderson) comb. nov.

59. Convolutispora sp.

60. Convolutispora sp. A

61. Convolutispora sp. B

62. Foveosporites karrooensis Anderson comb. nov.

63. Foveosporites sp.

64. Foveosporites sp. A

65. Foveosporites sp. B

66. Microreticulatisporites sp.

67. Microreticulatisporites sp. A

68. Clavatisporites sp.

69. Indotriradites australensis (Hart) Millsteed, 1999

70. Cristatisporites crassilabratus Archangelsky \& Gamerro, 1979

71. Cristatisporites inconstans Archangelsky \& Gamerro, 1979

72. Cristatisporites lestai Archangelsky \& Gamerro, 1979

73. Cristatisporites microvacuolatus (Dias-Fabrício) emend. Picarelli \& Dias-Fabrício, 1990

74. Cristatisporites morungavensis (Dias-Fabrício) emend. Picarelli \& Dias-Fabrício, 1990

75. Cristatisporites spinosus (Menendez \& Azcuy) Playford, 1978

76. Cristatisporites menendezii Playford, 1978

77. Cristatisporites sp.

78. Cristatisporites sp. A

79. Densoisporites sp.

80. Densosporites rotundus Falcon, 1978

81. Densosporites sp. 
82. Lundbladispora braziliensa (Pant \& Srivastava) emend. Marques-Toigo \& Picarelli, 1984

83. Lundbladispora gracila Stephenson \& Osterloff, 2002

84. Vallatisporites $\mathrm{sp}$.

85. Vallatisporites sp. A

86. Laevigatosporites vulgaris (Ibrahim) Ibrahim, 1933

87. Laevigatosporites plicatus Kar, 1968

88. Polypodiisporites mutabilis Balme, 1970

89. Polypodiisporites detritus (Leschik) Anderson, 1977

90. Florinites eremus Balme \& Hennelly, 1955

91. Striomonosaccites brevis Bose \& Kar, 1966

92. Striomonosaccites crucistriatus Ybert, 1975

93. Striomonosaccites sp.

94. Barakarites rotatus (Balme \& Hennelly) Bharadwaj \& Tiwari, 1964

95. Bascanisporites undosus Balme \& Hennelly, 1956

96. Cannanoropollis janakii Potonie \& Sah, 1960

97. Cannanoropollis sp.

98. Plicatipollenites gondwanensis (Balme \& Hennelly) Lele, 1964

99. Plicatipollenites densus Srivastava, 1970

100. Plicatipollenites trigonalis Lele, 1964

101. Plicatipollenites sp.

102. Plicatipollenites sp. A

103. Plicatipollenites sp. B

104. Caheniasaccites ovatus Bose \& Kar, 1966

105. Caheniasaccites flavatus Bose \& Kar, 1966

106. Potonieisporites novicus Bhardwaj, 1954

107. Potonieisporites brasiliensis (Nahuys, Alpern \& Ybert) Archangelsky \& Gamerro, 1979

108. Potonieisporites congoensis Bose \& Maheshwari, 1968

109. Illinites spectabilis (Leschik) comb. nov.

110. Limitisporites rectus Leschik, 1956

111. Limitisporites monstruosus (Luber in Luber \& Waltz) Hart, 1965

112. Limitisporites perspicuous (Leschik) comb. nov.

113. Limitisporites sp.

114. Vestigisporites rudis Balme \& Hennelly, 1955

115. Vestigisporites ventrisaccatus Anderson, 1977

116. Alisporites ovatus (Balme \& Hennelly) Jansonius, 1962

117. Alisporites australis de Jersey, 1962

118. Alisporites potoniei (Lakhanpal, Sah \& Dube) Somers, 1968

119. Alisporites splendens (Leschik) Foster, 1979

120. Platysaccus papilionis Potonié \& Klaus, 1954

121. Platysaccus sp.

122. Pteruchipollenites sp.

123. Hamiapollenites bullaeformis (Samoilovich) Jansonius, 1962

124. Hamiapollenites fusiformis (Marques-Toigo) emend. Archangelsky \& Gamerro, 1979

125. Hamiapollenites saccatus Wilson, 1962

126. Hamiapollenites tractiferinus (Samoilovich) Jansonius, 1962

127. Hamiapollenites sp.

128. Lueckisporites virkkiae Potonié \& Klaus, 1954

129. Lunatisporites nubilus (Leschik) comb. nov.

130. Lunatisporites variesectus Archangelsky \& Gamerro, 1979

131. Lunatisporites sp.

132. Protohaploxypinus haigii Foster, 1979
133. Protohaploxypinus hartii Foster, 1979

134. Protohaploxypinus limpidus (Balme \& Hennelly) Balme \& Playford, 1967

135. Protohaploxypinus perexiguus (Bharadwaj \& Salujha) Foster, 1979

136. Protohaploxypinus rugatus Segroves, 1969

137. Protohaploxypinus sp.

138. Striatoabieites multistriatus (Balme \& Hennelly) Hart, 1964

139. Striatopodocarpites cancellatus (Balme \& Hennelly) Hart, 1963

140. Striatopodocarpites fusus (Balme \& Hennelly) Potonié, 1958

141. Striatopodocarpites pantii (Jansonius) Balme, 1970

142. Striatopodocarpites rarus (Bharadwaj \& Salujha) Balme, 1970

143. Ephedripites sp.

144. Ephedripites sp. A

145. Vittatina densa Anderson, 1977

146. Vittatina foveolata Tschudy \& Kosanke, 1966

147. Vittatina scutata (Balme \& Hennelly) Bharadwaj, 1962

148. Vittatina minima Jansonius, 1962

149. Vittatina saccifer Jansonius, 1962

150. Vittatina subsaccata Samoilovich, 1953

151. Vittatina sp.

152. Vittatina sp. A

153. Weylandites lucifer (Bharadwaj \& Salujha) Foster, 1975

154. Weylandites magmus (Bose \& Kar) Backhouse, 1991

155. Pakhapites fusus (Bose \& Kar) Menéndez, 1971

156. Pakhapites ovatus (Bose \& Kar) Menéndez, 1971

157. Gnetaceaepollenites sp.

158. Pretricolpipollenites sp.

159. Marsupipollenites striatus (Balme \& Hennelly) Foster, 1975

160. Marsupipollenites triradiatus Balme \& Hennelly, 1956

161. Cycadopites cymbatus (Balme \& Hennelly) Hart, 1965

162. Cycadopites glaber (Luber \& Waltz) Hart, 1965

163. Cycadopites nevesi (Hart) Hart, 1965

164. Cycadopites follicularis Wilson \& Webster, 1946

165. Cycadopites sp.

166. Inapertisporites inapertus (Anderson) Falcon, 1978

167. Micrhystridium sp.

168. Tetraporina sp.

169. Veryhachium sp. A

170. Veryhachium sp. B

171. Veryhachium sp. C

172. Species A

173. Species B

174. Species C

175. Species D

176. Species E

177. Botryoccocus sp. cf. B. braunii

178. Arabisphaera bellula Hemer \& Nygreen, 1967

179. Arabisphaera sp.

180. Cymatiosphaera gondwanensis (Tiwari) Backhouse, 1991

181. Cymatiosphaera sp. A

182. Cymatiosphaera sp. B

183. Maculatasporites sp.

184. Tasmanites sp. 